\title{
MAGNESIUM SULFATE HEPTAHYDRATE AS PHASE CHANGE MATERIAL IN DOUBLE SLOPE SOLAR STILL
}

\author{
M. Khandagre ${ }^{1}$, B. Gupta ${ }^{2}$, J. Bhalavi ${ }^{3}$, P. Baredar ${ }^{4}$
}

\begin{abstract}
Solar still is best choice of utilizing freely available solar thermal energy to purify/desalinate muddy water. The driving force for this work is the inadequate availability of clean fresh water sources and the plenty of contaminated water available for probable conversion into potable water. Among various designs available, double basin passive solar still looks attractive for thermal applications in water prone and remote areas. This work presents experimental characterization of double slope solar still using phase change materials. This work aims to improve the performance (productivity of fresh water) using $\mathrm{Mg}_{2} \mathrm{SO}_{4} .7 \mathrm{H}_{2} \mathrm{O}$ as phase change material (PCM). Different tests were conducted for varying mass of the PCM. For experimentation, two identical double slope solar stills (basin area of $0.5 \times 0.5 \mathrm{~m}^{2}$ ) were designed, fabricated and tested for freshwater productivity. One is solar still (without PCM) and second with phase change material. A water depth of $5 \mathrm{~cm}$ was constant throughout the experimentation under climate conditions of Jabalpur $\left(23^{\circ} 10^{\prime} \mathrm{N}, 79^{\circ} 59^{\prime} \mathrm{E}\right)$, Madhya Pradesh India. The results obtained indicate that daily distillate for solar still with Magnesium sulfate heptahydrate is higher as compared to solar still without PCM. The convective heat transfer coefficient increases during the discharging period of PCM The daily freshwater productivity of $1400,1420 \& 1400 \mathrm{ml} / \mathrm{m}^{2} /$ day for solar still (without $\mathrm{Mg}_{2} \mathrm{SO}_{4} .7 \mathrm{H}_{2} \mathrm{O}$ ), while $1800,1900 \& 1960 \mathrm{ml} / \mathrm{m}^{2}$ day for the solar still (with $\mathrm{PCM}$ ) were recorded with addition of $0.5,0.75$ and $1 \mathrm{~kg}$ of $\mathrm{Mg}_{2} \mathrm{SO}_{4} .7 \mathrm{H}_{2} \mathrm{O}$ respectively. The overall thermal efficiency of the solar still with PCM was observed to be $64 \%$, and for a solar still without the PCM, it was $47 \%$ while the other conditions kept constant.
\end{abstract}

Keywords: Solar still, Desalination, Phase change materials, Magnesium sulfate heptahydrate, Productivity

\section{INTRODUCTION}

Humankind population is 7.69 billion (2019) worldwide out of which 663 million people are helpless to consume untreated water. It is anticipated to increase water demand by $55 \%$ in 2050 . India has population of more than 1.29 billion, out of this $70 \%$ distribution is of rural area. $30 \%$ population does not have access to drinkable water. The UN expects that $14 \%$ of the world's population will face water scarcity by 2025 . World's 21 out of 37 major underground water reservoirs are declining rapidly from India, China to the United States and France. This scarcity of drinking water-initiated water war and life-threatening health issues [1]. To overcome, solution is rainwater harvesting, purification of the water from available water resources using economical and prominent purification technologies. Solar stills are useful to produce drinking water, particularly in barren and inaccessible areas [2].

Water Desalination is one of such method, increasingly in use particularly semi-arid regions worldwide. The energy consumption, cost of equipment/material, lower distillation efficiency and environmental effects of desalination remain strategic anxieties for researchers and work is going on these fronts. So, low-cost water purification techniques (like solar desalination) are required to solve drinking water scarcity. Water desalination process refers to the removal of salts like sodium chloride and undesirable minerals from water so as to make it available for drinking purpose. This process produces pure and drinkable water that confirms the WHO water standards. Thermal energy storage in solar still is a significant way in conserving energy and improving its deployment $[3,4]$.

This paper was recommended for publication in revised form by Regional Editor Alibakhsh Kasaeian ${ }^{1}$ Research Scholar, Jabalpur Engineering College, Jabalpur - 482011, India

${ }^{2}$ Department of Mechanical Engineering, Jabalpur Engineering College, Jabalpur - 482011, India

${ }^{3}$ Department of Industrial \& Production, Jabalpur Engineering College, Jabalpur - 482011, India

${ }^{4}$ Department of Energy, Maulana Azad National Institute of Technology, Bhopal-462 051, India

Orcid id: 0000-0003-3712-0287, 0000-0001-9559-9578, 0000-0002-3025-9641, 0000-0002-8690-0741

${ }^{*}$ E-mail address: bhupendra243@yahoo.com

Manuscript Received 20 April 2019, Accepted 7 July 2019 
Desalinated water is generally healthier than ground water and river water. It contains less salt and limescales [5]. As the drinking water demand raising, this process increasingly more popular to serve in arid and semi-arid regions. The utmost users of desalinated water are in the Middle East countries (Bahrain, Saudi Arabia, Sudan, Israel, Iraq, Kuwait, Jordan and UAE), which consume nearly $70 \%$ of world capacity; and in North Africa (Algeria, Morocco, Libya and Tunisia), which consume nearly $6 \%$ of world capacity. In United States, California and Florida are frequent users of desalinated water for industrial and drinking purpose. Kuwait produces $100 \%$ of its water use by desalination process. Currently, $1 \%$ of the world's population depends on desalinated water to satisfy daily water needs. Worldwide 19,372 desalination plants operated till 2017, with capacity of 92 million cubic meters per day. Nearly 20,000 desalination plants have been installed worldwide (till 2019) and satisfies the water need of nearly 330 million humans (Source: According to the International Desalination Association). Desalination plants increased with a rate of $5 \%$ per year worldwide [6]. Water desalination generally performed by either of two key processes; (i) Membrane distillation to separate fresh water from a concentrate, (ii) Evaporation of water (phase-change or thermal processes). In membrane processes, energy/electricity is used for driving high pressure pumps or for forming electric fields to separate the ions. In thermal processes, distillation of water is achieved by consuming a thermal energy source, may be renewable energy source, like solar energy. Some other commonly methods in use are: Vacuum distillation, Multi-stage flash distillation, Multiple-effect distillation, Vapor-compression distillation, Reverse osmosis, solar evaporation and Electro-dialysis reversal [7]. Desalination's broader acceptance is limited due to various footraces such as: high energy consumption associates, high costs of setup/equipment, ongoing maintenance problems, etc. Research and development struggles on improving the materials involved in process (if membrane desalination or Reverse Osmosis) as well as the process of desalination itself. Water desalination was never feasible before 1995 on a commercial and industrial scale [8]. Solar energy is the best option to be incorporated with desalination process to reduce its energy consumption cost. Uniting solar energy to desalinate and purify water is the best choice. Thus, solar desalination now becoming the most prominent and economical feasible solution to satisfy drinking and industrial water needs. Solar desalination is considered as an economical as well as an ecological solution that uses solar energy to purify water. In India, more than 300 days of freely available solar energy can be utilized in solar desalination process such as solar still [9]. Solar still is a device which uses the Sun's heat energy to convert salty or muddy water into distilled drinkable water. Solar Still process replicates the natural water cycle or rain. In a solar still, impure water is contained in the basin and is evaporated by solar thermal energy entering through top glass cover. The pure water vapor condenses, drips down and collected. Water impurities such as salts and heavy metals remain in the basin. This process removes microbiological organisms as well. Finally collected water is pure distilled water [10]. There are various types and designs in operation including very large scale concentrated solar stills. Experimentation and Research is going on to make it cost effective and feasible solution. Its considerable types and designs include single/double basin, single/double slope, Concentrator Coupled, V type, Spherical, hemispherical, Pyramid, Tubular type and active solar stills. Key operating Parameters that affect productivity and distillate output are; Tilt angle, basin water depth, feed water flow rate, cover plat temperature, atmospheric temperature, humidity, convective heat transfer from cover plate and side walls, design of structure and shapes, solar tracking facility, absorber coatings, active or external enhancement arrangement like CPC, Temperature difference of basin water and top cover, nano particles addition, use of phase change materials (PCMs), etc. Lower distillate output, cost of equipment/fabrication/material, ongoing maintenance are some major problems associated with solar still [11]. Maximizing the contact surface area between the PCM and the absorber plate significantly enhances the outlet temperatures $[12,13]$. Using nanofluid in heat transfer field efficiency of equipment can be increased drastically $[14,15]$. By increasing the concentration of nano particles heat transfer coefficient can be enhanced [16, 17].

Broadly PCMs are classified as organic and inorganic materials. Inorganic PCMs have higher latent heat capacity when compared with organic [18]. Latent heat storage capacity ranges from 200-400 kJ/kg and 100-200 $\mathrm{kJ} / \mathrm{kg}$ for inorganic and organic PCMs respectively. The suspension of nano materials in fluids as particles has been the studied widely [19-21]. Encapsulation techniques of PCM have been successfully incorporated now a days. This provides separation of PCMs from other material and characterized by large heat transfer area [22].

In the given set up, for carrying out the trial of solar still as per the application temperature requirements salts such as $\mathrm{MgSO}_{4} .7 \mathrm{H}_{2} \mathrm{O}$ are attractive materials for use in thermal energy storage due to their high volumetric storage density, relatively high thermal conductivity and moderate costs compared to paraffin waxes or other PCM, with few exceptions. The PCM temperature is also reported to have values in a range (about 15 to $55^{\circ} \mathrm{C}$ 
for all the cases i.e. throughout the day. A wide range is there as the temperatures are recorded since morning to evening. In particular hour all the cases have close values. Further in previous work carried out by us a non-PCM material with similar thermal properties has been tried in our setup.

Wide ranges of non-PCMs have been investigated, in previous work it has observed that distilled output is increases during day time but not at par with PCM but the overall yield is lesser than PCM as heat storage materials. Pebble, granite stones, concrete stone, cow dung cakes etc. can be used as sensible Heat Storage material but it affects the purity of water and chances of contaminations are there.

In 2012, Kantesh et al. [23] designed a solar still for water desalination incorporating Bitumen as PCM for TES. The efficiency enhancement of nearly $9.3 \%$ was achieved. In 2015, Thakkar et al. [24] did study on solar still incorporating paraffin was as PCM along with nano-composite material. The distillate productivity enhancement of 90-106\% has been achieved. In 2015, Chaichan et al. [25] conducted experimentation on single slope solar still incorporating paraffin wax as PCM along with Aluminium powder to increase thermal conductivity of mixture. They reported better distillation time and distillate output. In 2015, Agrawal et al. [26] stated that solar distillation process is economical and beneficial in terms of lower energy consumption. They experimented on solar still with $40 \mathrm{~kg}$ of basin water with and without PCM on typical sunny days. They also reported better results incorporating PCM. In 2015, Rajasekhar et al. [27] did experimental investigation to enhance performance of single slope solar still with nano-composite $\left(\mathrm{Al}_{2} \mathrm{O}_{3}\right)$ and phase change material (paraffin wax). Experimental study gives that nano materials scattered in is giving better cumulative yield of pure water than PCM alone and without PCM thermal storage. The daily efficiency of the solar stills was found $45 \%, 40 \%$ and $38 \%$ incorporating paraffin wax with nano-composite, paraffin wax alone as thermal storage and base solar still respectively. In 2015, Deshmukh et al. [28] experimentally compared conventional solar still (without PCM storage material) and still (with bee wax). They found that depth of water increases the overnight productivity using PCM, but daytime productivity is found to be less. In 2016, Kumar et al. [29] experimentally compared conventional solar still (without PCM storage material) and still (with Lauric acid). They found that the exergy efficiency increases by $40 \%$ when Lauric acid is used as PCM in the solar still. In 2016, Hamed et al. [30] developed a theoretical model for study of flat plate solar collector (with a phase change material). They used Matlab software to compute energy balance equations of the flat palate solar collector. In 2016, Senthil et al. [31] experimentally compared conventional solar still (without PCM and still with paraffin wax. Different depth of water has been taken for the experiment $(10,20$ and $30 \mathrm{~mm})$. Basin water depth of $10 \mathrm{~mm}$ was reported best distillate output. 10-11 \% fresh water yield enhancement was found while incorporating PCM. In 2016, Patil et al. [32] experimented with single basin, double slope solar still incorporating paraffin wax as PCM (latent heat storage) and sensible heat storage material black pebbles. A double slope single basin solar still with area of $0.7 \mathrm{~m}^{2}$ was fabricated with Aluminum sheet metal and experiment was carried out in open environment conditions. An Aluminum tray of $0.40 \mathrm{~m}^{2}$ is placed inside the still giving $10 \mathrm{~cm}$ gap. Remaining set of readings (with PCM and SHSE) were compared with standard readings and analysis has been done. Thus the percentage productivity observed in case of Paraffin wax and black coated tray is $30 \%$, black pebbles and black coated tray is $18 \%$, Paraffin wax and black pebbles is $13 \%$. In 2017, Dubey et al. [33] investigated the performance of stepped solar still with pyramidal glass cover incorporating stearic acid as PCM. The conventional techniques used for desalination consume large amount of input energy. Use of phase change material is best practice for improving the performance of solar still. In 2017, A.E.

PCMs have wide range with respect to its melting range, latent heat, volume expansion, density and thermal conductivity $[34,35]$. Latent heat energy storage for solar applications is gaining more attention due to its compactness, high energy storage density and occurring at nearly constant temperature [36].

Kabeel et al. [37] theoretically compared the performance of modified solar still incorporating different phase change materials for thermal energy storage with conventional solar still. Three phase change materials are used to choose the best one. The system productivity is increased by about 120 to $198 \%$ while the system working time increased to 2 to 3 hrs. In 2017, Ravi Kumar et al. [38] investigated and compared three different types of solar still setups. (i) Conventional setup, (ii) incorporating black stones placed over the bottom of the plate, (iii) incorporating Paraffin wax as PCM. The mixture of titanium oxide and paraffin wax was poured into the copper tube and placed over the surface plate. Solar energy stored large quantity in day period lesser in night time by the paraffin wax liberates its stored heat. The absorbed heat energy cannot escape in the chamber. Because the double glass solar still fully insulated by Polyurethane Foam. Modified setup resulted in improved fresh water production rates at different session. In 2017, Husainy et al. [39] experimentally compared two 
different setups of double slope single basin solar still with and without thermal energy storage by phase change material. The distillate production has been increased in the range of $10-25 \%$ when incorporating paraffin wax as PCM. In 2017, Pal et al. [40] experimented on multi basin, double slope, and multi-wick solar still with $2 \mathrm{~cm}$ basin water depth. They reported $23.03 \%$ and $20.94 \%$ distillate improvement while incorporated black cotton wick and jute wick respectively over conventional setup. Maximum distillate were $9012 \mathrm{ml} /$ day and $7040 \mathrm{ml} /$ day reported for black cotton wick and jute wick respectively. In 2018, Kulkarni et al. [41] performed experiments on stepped double slope solar still and compared with conventional one. They incorporated PCM and reported better results with water productivity nearly 5 liters /day. They also reported that distilled water has $\mathrm{pH}$ of 6.95 (more nearer to 7) as compared to the $7.80 \mathrm{pH}$ of brackish water. In 2018, Kabeel et al. [42] theoretically studied the performance of various phase change materials on solar still. They found that inorganic PCM capric-palmatic and organic PCM A48 are most suitable in terms of higher productivity and lower cost for solar still applications. They recommend the use of small thickness PCMs, as its thickness has no remarkable effect on the productivity. In 2019, Cheng et al. [43] evaluated performance of solar still experimentally and through simulation model using shape-stabilized phase change materials. Results reported that daily productivity of modified solar still was 43.3\% higher than that of conventional solar still without PCM. In 2016, Kabeel et al. [44] experimentally compared the performance of conventional solar still and modified solar still (with injected hot air and PCM). Distillate output of nearly $9.36 \mathrm{~L} / \mathrm{m}^{2}$ day has been reported for double passes solar air collector-coupled modified solar still with PCM. Modified solar still performed $108 \%$ better as compared to conventional still. In 2017, Faegh et al. [45] experimented on solar still incorporated with external condenser packed-filled with PCM as latent heat storage. They reported distillate output of $6.555 \mathrm{~kg} / \mathrm{m}^{2}$ day with an increase by $86 \%$.

A lot of research work has already been done by using different heat storage material as a phase change material but in the literature the performance of solar still using phase change material like magnesium sulfate heptahydrate has not observed much or very little work is available.

Earlier findings in the field show that when this material is produced in a TC storage energy system with the packed bed reactor of porosity $50 \%$, can allow a storage density of $1 \mathrm{GJ} / \mathrm{m}^{3}$.

However, under low vapor pressure conditions, the material has slow reaction kinetics. This low vapor pressure condition normally occurs in seasonal heat storage ( $13 \mathrm{mbar}$ ). The study presented in the paper indicates that the dehydration process of $\mathrm{MgSO}_{4} .7 \mathrm{H}_{2} \mathrm{O}$ enhances at higher vapor pressure conditions (50 mbar) in turn enhancing the performance of the material.

It was found that the material was able to take up and release almost 10 times more energy than water of the same volume.

\section{CLASSIFICATION AND SELECTION OF PCMS}

Broadly PCMs are classified as organic and inorganic materials. Inorganic PCMs have higher latent heat capacity when compared with organic. Latent heat storage capacity ranges from $200-400 \mathrm{~kJ} / \mathrm{kg}$ and $100-200$ $\mathrm{kJ} / \mathrm{kg}$ for inorganic and organic PCMs respectively.

\section{Organic Phase Change Materials}

Organic PCMs can further be classified as paraffin and non-paraffin materials. They have been extensively employed for Thermal energy storage (TES) applications because of their non-corrosiveness conduct. Table 1 gives different organic PCMs with their latent heat capacity and melting point [46].

Table 1. Latent heat of fusion and melting point and for some Organic PCMs (fatty acid).

\begin{tabular}{|l|c|c|}
\hline Material & Melting point $\left({ }^{\circ} \mathrm{C}\right)$ & Latent heat $(\mathbf{k J} / \mathbf{k g})$ \\
\hline Eladic acid & 47 & 218 \\
\hline Lauric acid & 49 & 178 \\
\hline Pentadecanoic acid & 52.5 & 178 \\
\hline Tristearin acid & 56 & 191 \\
\hline Myristic acid & 58 & 199 \\
\hline Palmatic acid & 55 & 163 \\
\hline Stearic acid & 69.4 & 199 \\
\hline
\end{tabular}




\section{Inorganic Phase Change Materials}

Inorganic PCMs can further be classified as salt hydrate, metallic materials and alloys. These are characterized by high latent heat, higher thermal conductivity, non-flammability, non-toxicity, and lower cost comparatively [47].

\section{Metallic PCMs}

This metallic PCM includes the low melting metals and metal eutectics. Metallic PCM considered very less because of their heavier weight.

\section{Salt Hydrates (Ionic Liquid)}

Hydrates are generally used for thermal energy storage. They can be defined as inorganic salts "containing water molecules combined in a certain ratio forming a typical crystalline solid". It belongs to general formula of $\mathrm{AB} \cdot \mathrm{nH}_{2} \mathrm{O}$ (example: $\mathrm{MgSO}_{4} \cdot 7 \mathrm{H}_{2} \mathrm{O}$ ). The anhydrous salt settles down at the bottom of the container, it is due to density difference. Salt hydrates are characterized by; High latent heat, High thermal conductivity, noncorrosive, nearly non-toxic, economical. Some salt hydrates with suitable melting point and high latent heat are tabulated in Table 2 [48].

Table 2. Melting point and latent heat of fusion for some salt hydrates

\begin{tabular}{|l|c|c|}
\hline Material & Melting point $\left({ }^{\circ} \mathrm{C}\right)$ & Latent heat ( KJ/kg) \\
\hline $\mathrm{Zn}\left(\mathrm{NO}_{3}\right)_{2} .2 \mathrm{H}_{2} \mathrm{O}$ & 55 & 68 \\
\hline $\mathrm{FeCl}{ }_{3} 2 \mathrm{H}_{2} \mathrm{O}$ & 56 & 90 \\
\hline $\mathrm{K}_{2} \mathrm{HPO}_{4} \cdot 3 \mathrm{H}_{2} \mathrm{O}$ & 48 & 99 \\
\hline $\mathrm{Ca}\left(\mathrm{NO}_{3}\right)_{2} .3 \mathrm{H}_{2} \mathrm{O}$ & 51 & 104 \\
\hline $\mathrm{Ca}\left(\mathrm{NO}_{3}\right) .4 \mathrm{H}_{2} \mathrm{O}$ & 47 & 153 \\
\hline $\mathrm{Zn}\left(\mathrm{NO}_{3}\right)_{2} \cdot 4 \mathrm{H}_{2} \mathrm{O}$ & 45 & 110 \\
\hline $\mathrm{Na}_{2} \mathrm{SiO}_{3} \cdot 4 \mathrm{H}_{2} \mathrm{O}$ & 48 & 168 \\
\hline $\mathrm{Na}_{2} \mathrm{~S}_{2} \mathrm{O}_{3} .5 \mathrm{H}_{2} \mathrm{O}$ & 48.5 & 210 \\
\hline $\mathrm{MgSO}_{4} \cdot 7 \mathrm{H}_{2} \mathrm{O}$ & 48.5 & 202 \\
\hline $\mathrm{Mg}\left(\mathrm{NO}_{3}\right) \cdot 4 \mathrm{H}_{2} \mathrm{O}$ & 47 & 142 \\
\hline $\mathrm{Fe}\left(\mathrm{NO}_{3}\right) \cdot 9 \mathrm{H}_{2} \mathrm{O}$ & 47 & 155 \\
\hline
\end{tabular}

The choice and selection of suitable PCM for a given application depends upon number of factors. Chemical stability, thermodynamic and economic properties affects its selection criteria for TES applications. Desirable thermal properties are; high latent heat of fusion per unit volume of material, high thermal conductivity, appropriate phase-transformation temperature, lower charging and discharging times, uniform distribution of the temperature. Desirable physical properties are; high density, small volume change, promising phase equilibrium. Apart from this, PCMs must be available commercially at low cost and abundant quantity [49]. PCMs incorporated with solar still for TES application include; Paraffin wax $\left(\mathrm{T}_{\mathrm{m}}: 60^{\circ} \mathrm{C}\right)$, Paraffin wax with $\mathrm{Al}_{2} \mathrm{O}_{3}$ as nano material, Bees wax $\left(\mathrm{T}_{\mathrm{m}}: 64.22{ }^{\circ} \mathrm{C}\right)$, Lauric Acid $\left(\mathrm{T}_{\mathrm{m}}: 43{ }^{\circ} \mathrm{C}\right)$, Stearic Acid $\left(\mathrm{T}_{\mathrm{m}}: 70^{\circ} \mathrm{C}\right)$, Myristic Acid $\left(\mathrm{Tm}-50-54^{\circ} \mathrm{C}\right)[50]$. PCMs can be an excellent selection to enhance the thermal energy storage capacity of thermal system [51]. Thermal energy storage (TES) Systems with phase change materials (PCMs) as a known energy storage technology has a high potential for increasing the energy efficiency of buildings [52].

Phase change materials (PCMs) have the characteristics to absorb high amount of thermal energy during changing the solid-liquid interface [53-55].

Microencapsulated PCM technique has been developed for inhibiting interaction of PCM with the environment and increasing the heat transfer area [56].

\section{EXPERIMENTAL SET UP}

Two identical double slope, single basin solar stills designed, fabricated and tested under same environmental conditions. Their distillate performance have been compared. First solar still works as conventional one while second still incorporated with capsules of Magnesium Sulfate Heptahydrate $\left(\mathrm{MgSO}_{4} \cdot 7 \mathrm{H}_{2} \mathrm{O}\right)$ as phase change material inside basin water. 
Figure 1 shows a pictorial view and Figure 2 displays schematic diagram of the solar stills. Basin surface area for both the solar stills are $0.5 \times 0.5 \mathrm{~m}^{2}$. It has maximum wall height of $0.27 \mathrm{~m}$ and minimum of $0.12 \mathrm{~m}$. Absorber surface painted black to enhance solar radiation absorption into basin. Rectangular Cast Iron sheet with $1 \mathrm{~mm}$ thickness is used to prepare setup. Plywood with $10 \mathrm{~mm}$ thickness is used to provide support to outside walls of solar still. The top cover of still is made with $4 \mathrm{~mm}$ thick glass plate and it is inclined by $23^{\circ}$ to the horizontal. Both solar stills were insulated well from side and bottom surfaces with thermocol material. Glass putti is used to provide packing throughout the setup to avoid leak. $5 \mathrm{~cm}$ basin water depth has been taken for all the experiments. The setup was facing south direction to capture maximum solar insolation.

The condensate water is collected in galvanized iron channel fixed at the lower end side of the glass covers. Set up is well equipped with instruments such as digital display thermometer to measure the temperatures of various sections of solar stills (inside glass, outside glass, basin water and vapour temperature). Temperatures at five different pre-defined points have been measured along with atmospheric temperature. Solar power meter and marked container bottle were incorporated to measure solar insolation in $\mathrm{W} / \mathrm{m}^{2}$ and fresh water outlet in liter/hour respectively.

The experiments were conducted from 8:00 A.M to 6:00 P.M during Nov. 2018. The k-type thermocouples were utilized to measure the temperatures of PCM, basin, glass, ambiance, and water. The solar intensity is measured by the Kipp-Zonen Solarimeter. The measurement of the ambient air velocity was provided by an anemometer. The distillate output from the still was measured, using a measuring jar.

The instruments which are used for measuring different parameters, like temperature, wind velocity, radiation and distillate output there accuracy range have been mentioned in Table 3 and standard uncertainty and observed error have been found as given in Table 4.

Table 3. Accuracy, range and errors for measuring instruments

\begin{tabular}{|l|c|c|c|}
\hline Instruments & Accuracy & Range & $\begin{array}{l}\text { \% } \\
\text { Error }\end{array}$ \\
\hline Thermocouple & $\pm 0.1^{\circ} \mathrm{C}$ & $0^{\circ} \mathrm{C}$ to $100^{\circ} \mathrm{C}$ & 0.5 \\
\hline Kipp-Zonen Solarimeter & $\pm 1 \mathrm{~W} / \mathrm{m}^{2}$ & $0 \mathrm{~W} / \mathrm{m}^{2}$ to $5000 \mathrm{~W} / \mathrm{m}^{2}$ & 0.25 \\
\hline Anemometer & $\pm 0.1 \mathrm{~m} / \mathrm{s}$ & $0 \mathrm{~m} / \mathrm{s}$ to $15 \mathrm{~m} / \mathrm{s}$ & 10 \\
\hline Measuring jar & $\pm 10 \mathrm{ml}$ & $0 \mathrm{ml}$ to $1000 \mathrm{ml}$ & 10 \\
\hline
\end{tabular}

Table 4. Observed error and standard uncertainty

\begin{tabular}{|l|c|c|}
\hline Instruments & Observed error & Standard Uncertainty \\
\hline Thermocouple & 1.1 & $\pm 0.56{ }^{\circ} \mathrm{C}$ \\
\hline Kipp-Zonen Solarimeter & 3.2 & $\pm 0.55 \mathrm{~W} / \mathrm{m}^{2}$ \\
\hline Anemometer, & 6.7 & $\pm 0.06 \mathrm{~m} / \mathrm{s}$ \\
\hline Measuring jar, & 8.2 & $\pm 5.74 \mathrm{ml}$ \\
\hline
\end{tabular}

Different sets of experiments have been performed for different weights of PCM encapsulated into basin water. The concentration of Magnesium Sulfate Heptahydrate $\left(\mathrm{MgSO}_{4} .7 \mathrm{H}_{2} \mathrm{O}\right)$ as $\mathrm{PCM}$ varies from $25,37.5$ \& 50 grams in each of 20 capsules placed in modified solar still. Total weight of PCM incorporated in different sets were 500, 750 and $1000 \mathrm{~g}$. Table 5 gives design features/calculations of PCM capsules. The properties of $\mathrm{MgSO}_{4} .7 \mathrm{H}_{2} \mathrm{O}$ used as PCM is given in Table 6.
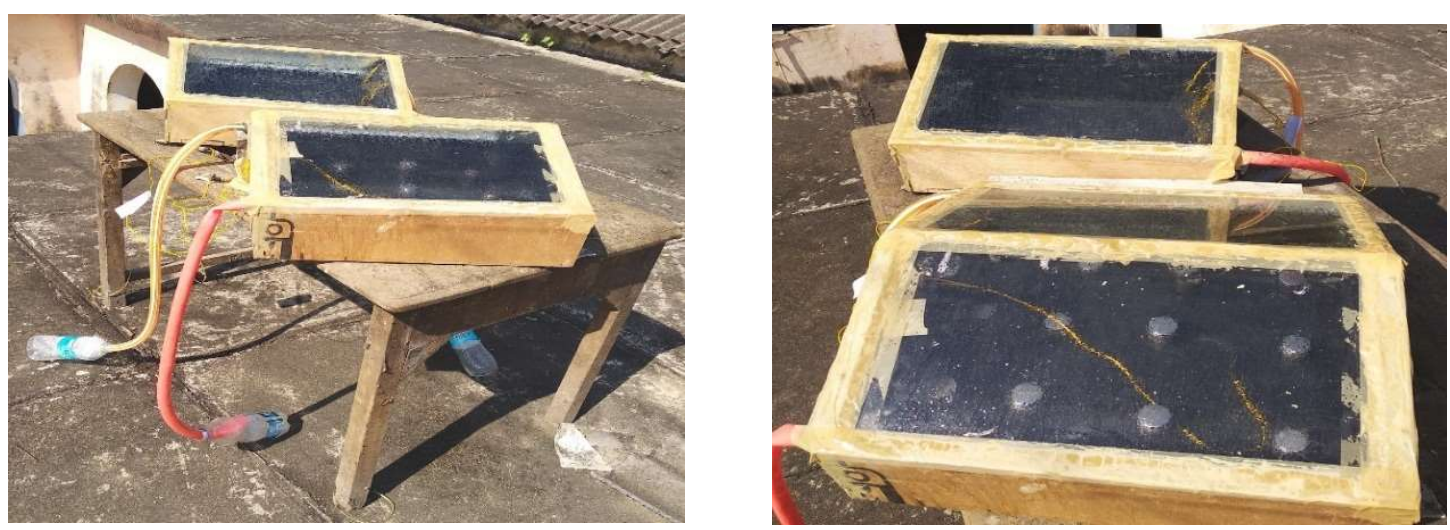

Figure 1. Photographic view of the experimental setup 
Journal of Thermal Engineering, Research Article, Vol. 7, No. 2, Special Issue 13, pp. 196-214, February, 2021

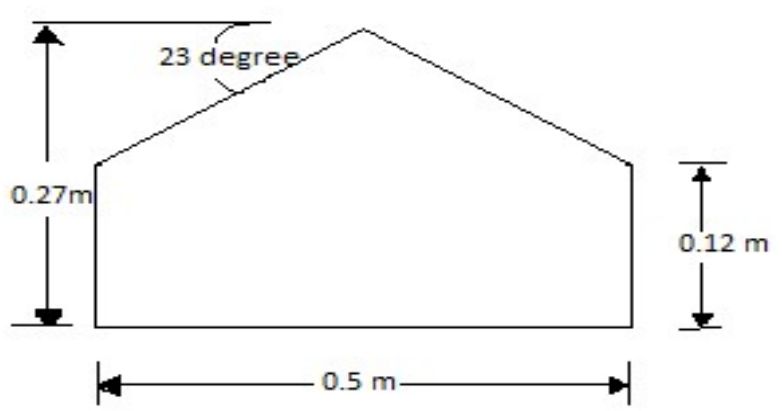

Figure 2. Schematic diagram of solar stills.

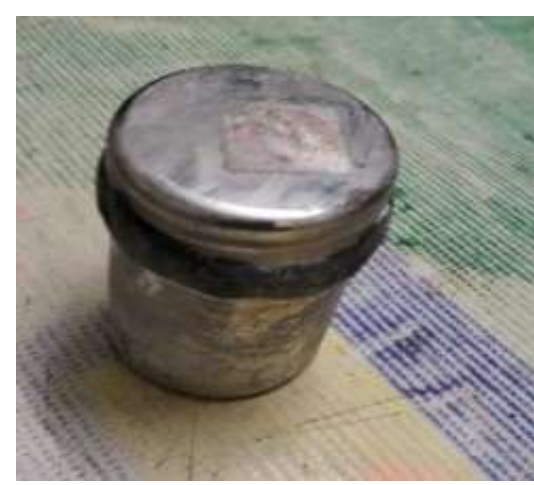

Figure 3. Photograph of the PCM capsule used.

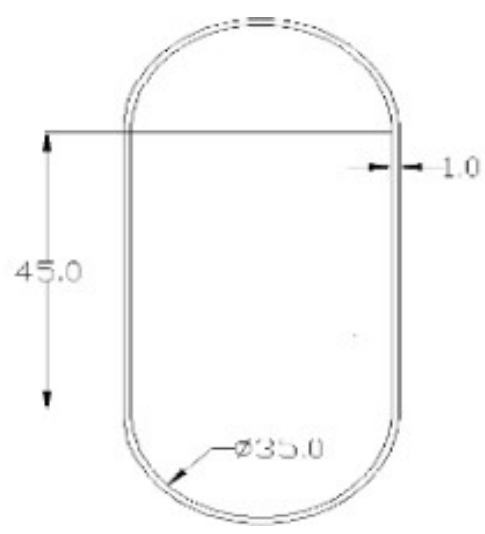

Figure 4. Dimensions of PCM capsule used in experiment (in $\mathrm{mm}$ ).

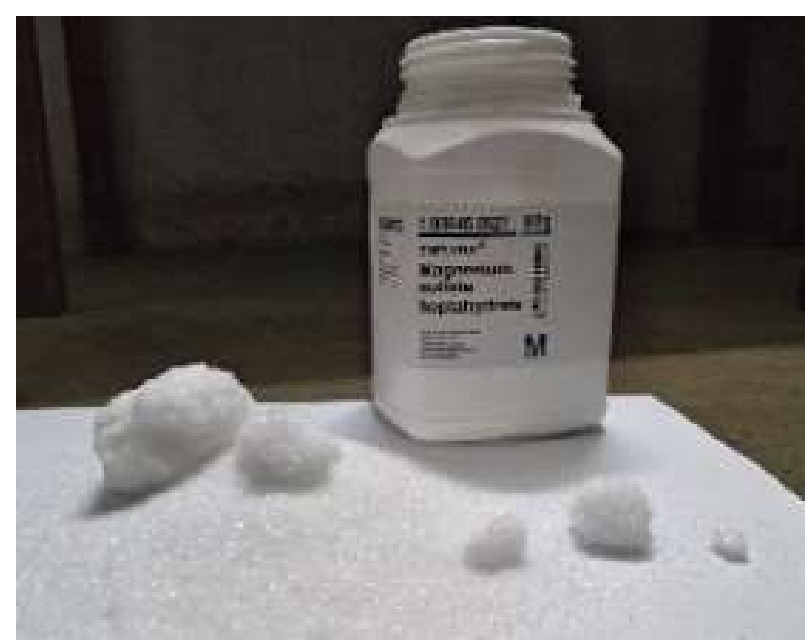

Figure 5. Photograph of the PCM used. 
Table 5. Design features/calculations of PCM capsule

\begin{tabular}{|c|l|c|}
\hline S. N. & Properties/dimension & Value \\
\hline 1 & Weight of capsule (vacant) & $50 \mathrm{~g}$ \\
\hline 2 & Diameter & $3.5 \mathrm{~cm}$ \\
\hline 3 & Height & $4.5 \mathrm{~cm}$ \\
\hline 4 & Volume & $43.27 \mathrm{~cm}^{3}$ \\
\hline
\end{tabular}

Table 6. Properties of $\mathrm{MgSO}_{4} \cdot 7 \mathrm{H}_{2} \mathrm{O}$ used as $\mathrm{PCM}$

\begin{tabular}{|c|l|c|}
\hline S. N. & Properties & Value \\
\hline 1 & Density & $2.66 \mathrm{~g} / \mathrm{cm}^{3}$ \\
\hline 2 & Molar mass & $246.47 \mathrm{~g} / \mathrm{mole}$ \\
\hline 3 & Odor & odorless \\
\hline 4 & Soluble in water & $1139 / 100 \mathrm{ml}\left(20^{\circ} \mathrm{C}\right)$ \\
\hline 5 & T $_{\text {melting }}$ & $48.5^{\circ} \mathrm{C}$ \\
\hline 7 & Latent heat & $202 \mathrm{KJ} / \mathrm{Kg}$ \\
\hline 8 & Reflective index & 1.433 \\
\hline
\end{tabular}

\section{METHODOLOGY}

All the experiments were conducted between the time periods of 08:00 to 18:00hrs. These experiments were conducted in November at JEC Jabalpur, Madhya Pradesh state (India). This site is $23^{\circ} 10^{\prime}$ North latitude and $79^{\circ} 59^{\prime}$ East longitude, with an altitude of around 411 meters. The solar irradiance is monitored on PC system. Thermo couples were fixed to take the temperature of water, PCM, glass, insulation and ambient temperature. The $5 \mathrm{~cm}$ height water depth is filled brackish or saline water. All the temperature measurements, measurements of irradiances on the horizontal and inclined plane, and mass flow rates of distilled water were sampled every 1 hour. The readings were taken for two experimental setups (a) with PCM and (b) without PCM.

There were 3 reading setups designed. First setup incorporated with 20 numbers of capsule into basin water, each filled with $25 \mathrm{~g}$ of Magnesium Sulfate Heptahydrate $\left(\mathrm{MgSO}_{4} .7 \mathrm{H}_{2} \mathrm{O}\right)$ as PCM material. Similarly, second and third setups were conducted with same 20 numbers of capsules each filled with $37.5 \mathrm{~g}$ and $50 \mathrm{~g}$ of Magnesium Sulfate Heptahydrate $\left(\mathrm{MgSO}_{4} .7 \mathrm{H}_{2} \mathrm{O}\right)$ respectively.

Hourly, daytime and overall distillate outputs have been compared for all these three setups with conventional solar still. Temperatures and distillate output readings captured hourly from morning 8 am to $6 \mathrm{pm}$. Also, $T_{\text {atm }}, T_{\text {inside glass, }}, T_{\text {outside glass, }}, T_{\text {vapour }}, T_{\text {basin water }}$ were recorded carefully. Night-time or off-sun time distillate has been measured till next day $8.00 \mathrm{am}$. Thus, daytime, night-time and overall distillate have been measured for each experimental set.

The effect different weight concentration of $\mathrm{MgSO}_{4} .7 \mathrm{H}_{2} \mathrm{O}$ as $\mathrm{PCM}$ in solar still have been evaluated.

\section{RESULTS AND DISCUSSION}

\section{Variation of atmospheric temperature with solar radiation}

Figure 6,7 and 8 show typical hourly variation of atmospheric temperature with solar radiation for three different dates; $01 / 11 / 2018,04 / 11 / 2018$ and 08/11/2018 on Jabalpur, India respectively. The curves follow parabolic nature. The peaks of both atmospheric temperature and solar intensity were observed between 2 to 3 pm afterwards decreases steadily. The nature of curves on the above dates is showing first increasing gradually, reaches at the peak at around 1-2 PM. Then started decreasing gradually. Same nature has been shown in all the days.

Maximum solar radiation of $750 \mathrm{~W} / \mathrm{m}^{2}, 750 \mathrm{~W} / \mathrm{m}^{2}$ and $775 \mathrm{~W} / \mathrm{m}^{2}$ and peak ambient temperature of 33.5 ${ }^{\circ} \mathrm{C}, 33.6^{\circ} \mathrm{C}$ and $34.9^{\circ} \mathrm{C}$ were recorded on $01 / 11 / 2018,04 / 11 / 2018$ and $08 / 11 / 2018$ respectively. Almost zero solar radiation received after $6 \mathrm{pm}$ on corresponding days. 


\section{Variation of solar still temperatures at different positions with solar radiation}

Figure 9 displays variation of conventional solar still temperatures (without PCM) at different positions with solar radiation. Maximum solar radiation of $750 \mathrm{~W} / \mathrm{m}^{2}$ has been recorded. The temperatures at different location have been measured to see the performance of solar still. Highest temperatures at different positions of solar still recorded are; $\mathrm{T}_{\mathrm{atm}}, \mathrm{T}_{\mathrm{go}}, \mathrm{T}_{\mathrm{gi}}, \mathrm{T}_{\mathrm{v}}, \mathrm{T}_{\mathrm{w}}$ of $33.5^{\circ} \mathrm{C}, 38^{\circ} \mathrm{C}, 48^{\circ} \mathrm{C}, 49^{\circ} \mathrm{C}$ and $51^{\circ} \mathrm{C}$ respectively. Trial was taken on conventional solar still (Test conducted on 01 November 2018).

Figure 10 displays variation of modified solar still temperatures (with $0.5 \mathrm{Kg}$ of $\mathrm{MgSO}_{4} .7 \mathrm{H}_{2} \mathrm{O}$ ) at different positions with solar radiation. Maximum solar radiation of $750 \mathrm{~W} / \mathrm{m}^{2}$ has been recorded. Highest temperatures at different positions of solar still recorded are; $\mathrm{T}_{\mathrm{atm}}, \mathrm{T}_{\mathrm{go}}, \mathrm{T}_{\mathrm{gi}}, \mathrm{T}_{\mathrm{v}}, \mathrm{T}_{\mathrm{w}}, \mathrm{T}_{\mathrm{pcm}}$ of $33.5^{\circ} \mathrm{C}, 38^{\circ} \mathrm{C}, 49^{\circ} \mathrm{C}$, $50^{\circ} \mathrm{C}, 50^{\circ} \mathrm{C}$ and $54^{\circ} \mathrm{C}$ respectively. Throughout the day the nature of curve is first increasing gradually reaching at the peak then decreasing gradually. As compared to the without PCM the different temperatures recorded are more. This implies that better heat storage effect has been observed.

Figure 11 displays variation of conventional solar still temperatures (without PCM) at different positions with solar radiation. Maximum solar radiation of $750 \mathrm{~W} / \mathrm{m}^{2}$ has been recorded. Highest temperatures at different positions of solar still recorded are; $\mathrm{T}_{\mathrm{atm}}, \mathrm{T}_{\mathrm{go}}, \mathrm{T}_{\mathrm{gi}}, \mathrm{T}_{\mathrm{v}}, \mathrm{T}_{\mathrm{w}}$ of $33.6^{\circ} \mathrm{C}, 39^{\circ} \mathrm{C}, 42^{\circ} \mathrm{C}, 43^{\circ} \mathrm{C}$ and $46^{\circ} \mathrm{C}$ respectively. Trial was taken on conventional solar still (Test conducted on 04 November 2018).

Figure 12 displays variation of modified solar still temperatures (with $0.75 \mathrm{Kg}$ of $\mathrm{MgSO}_{4} .7 \mathrm{H}_{2} \mathrm{O}$ ) at different positions with solar radiation. Here the quantity of PCM has increased by $0.25 \mathrm{~kg}$. And its effect has been observed. A little bit enhancement in the temperature have been observed. Maximum solar radiation of $750 \mathrm{~W} / \mathrm{m}^{2}$ has been recorded. Highest temperatures at different positions of solar still recorded are; $\mathrm{T}_{\mathrm{atm}}, \mathrm{T}_{\mathrm{go}}, \mathrm{T}_{\mathrm{gi}}$, $\mathrm{T}_{\mathrm{v},} \mathrm{T}_{\mathrm{w}}, \mathrm{T}_{\mathrm{pcm}}$ of $33.6^{\circ} \mathrm{C}, 39^{\circ} \mathrm{C}, 45^{\circ} \mathrm{C}, 47^{\circ} \mathrm{C}, 48^{\circ} \mathrm{C}$ and $55^{\circ} \mathrm{C}$ respectively.

Figure 13 displays variation of conventional solar still temperatures (without PCM) at different positions with solar radiation. Maximum solar radiation of $775 \mathrm{~W} / \mathrm{m}^{2}$ has been recorded. Highest temperatures at different positions of solar still recorded are; $\mathrm{T}_{\mathrm{atm}}, \mathrm{T}_{\mathrm{go}}, \mathrm{T}_{\mathrm{gi}}, \mathrm{T}_{\mathrm{v}}, \mathrm{T}_{\mathrm{w}}$ of $34.9^{\circ} \mathrm{C}, 40^{\circ} \mathrm{C}, 48^{\circ} \mathrm{C}, 50^{\circ} \mathrm{C}$ and $52^{\circ} \mathrm{C}$ respectively. Trial was taken on conventional solar still (Test conducted on 08 November 2018).

Figure 14 displays variation of modified solar still temperatures (with $1 \mathrm{Kg}$ of $\mathrm{MgSO}_{4} .7 \mathrm{H}_{2} \mathrm{O}$ ) at different positions with solar radiation. As the quantity of PCM has further increased to $1 \mathrm{~kg}$ and the performance is monitored. Maximum solar radiation of $775 \mathrm{~W} / \mathrm{m}^{2}$ has been recorded. Highest temperatures at different positions of solar still recorded are; $\mathrm{T}_{\mathrm{atm}}, \mathrm{T}_{\mathrm{go}}, \mathrm{T}_{\mathrm{gi}}, \mathrm{T}_{\mathrm{v}}, \mathrm{T}_{\mathrm{w}}, \mathrm{T}_{\mathrm{pcm}}$ of $34.9^{\circ} \mathrm{C}, 39^{\circ} \mathrm{C}, 47^{\circ} \mathrm{C}, 49^{\circ} \mathrm{C}, 51^{\circ} \mathrm{C}$ and $54^{\circ} \mathrm{C}$ respectively. So, it is observed that as the quantity of PCM increased, the heat storage effect has been increased drastically.

\section{Hourly output variation with daylight time}

Figure 15 displays variation of distillate output for both the stills with daytime on hourly basis from 8 am to $6 \mathrm{pm}$. Yield have been measured on hourly basis. At the end of the day maximum distillate output of 550 $\mathrm{ml}$ were recorded in modified solar still having $0.5 \mathrm{~kg}$ of encapsulated $\mathrm{MgSO}_{4} .7 \mathrm{H}_{2} \mathrm{O}$ as compared to $350 \mathrm{ml}$ in conventional solar still. While the rest of condition kept constant. (Test conducted on 01 November 2018).

Figure 16 displays variation of distillate output for both the stills with day time on hourly basis from 8 am to $6 \mathrm{pm}$. Yield have been measured on hourly basis. At the end of the day maximum distillate output of 475 $\mathrm{ml}$ were recorded in modified solar still having $0.75 \mathrm{~kg}$ of encapsulated $\mathrm{MgSO}_{4} .7 \mathrm{H}_{2} \mathrm{O}$ as compared to $355 \mathrm{ml}$ in conventional solar still. While the rest of condition kept constant. (Test conducted on 04 November 2018).

Figure 17 displays variation of distillate output for both the stills with day time on hourly basis from 8 am to $6 \mathrm{pm}$. Yield have been measured on hourly basis. At the end of the day maximum distillate output of 490 $\mathrm{ml}$ were recorded in modified solar still having $1 \mathrm{~kg}$ of encapsulated $\mathrm{MgSO}_{4} \cdot 7 \mathrm{H}_{2} \mathrm{O}$ as compared to $350 \mathrm{ml}$ in conventional solar still. While the rest of condition kept constant. (Test conducted on 08 November 2018).

Figure 18 shows hourly temperature of PCM versus time on all the three days (01/11/18, 04/11/18 and $08 / 1 / 18$ ) from $10 \mathrm{am}$ to $4 \mathrm{pm}$ for all the three cases showing comparison at a glance. It is inferred that the hourly temperature of PCM in all the three cases it was on a gradual path by reaching at its peak at around $1 \mathrm{pm}$ and the maximum was at $3 \mathrm{pm}$ then the hourly temperature was gradually decreasing. Further it also cleared that as the quantity of phase change material is increasing hourly temperature also increases. Showing little bit enhancement in the heat storage effect.

\section{Daily productivity}

Figure 19 displays day-productivity and overall productivity of freshwater output in both the solar stills. Overall productivity ( $24 \mathrm{hrs}$. basis) of $450 \mathrm{ml} / 0.25 \mathrm{~m}^{2}$ were recorded in modified solar still (encapsulated with 0.5 
$\mathrm{kg}$ of $\mathrm{MgSO}_{4} .7 \mathrm{H}_{2} \mathrm{O}$ ) as compared to $350 \mathrm{ml} / 0.25 \mathrm{~m}^{2}$ in conventional solar still. While, day-time productivity (8 am to $6 \mathrm{pm}$ ) of $350 \mathrm{ml} / 0.25 \mathrm{~m}^{2}$ were recorded in modified solar still as compared to $310 \mathrm{ml} / 0.25 \mathrm{~m}^{2}$ in conventional solar still. The performance has been monitored for day time as well as day night time. As there will be storage effect inside the solar still so at night time also there will be yield of fresh water.

Figure 20 displays day-productivity and overall productivity of fresh water output in both the solar stills. Overall productivity ( $24 \mathrm{hrs}$. basis) of $475 \mathrm{ml} / 0.25 \mathrm{~m}^{2}$ were recorded in modified solar still (encapsulated with $0.5 \mathrm{~kg}$ of $\mathrm{MgSO}_{4} .7 \mathrm{H}_{2} \mathrm{O}$ ) as compared to $355 \mathrm{ml} / 0.25 \mathrm{~m}^{2}$ in conventional solar still. While, day-time productivity $\left(8 \mathrm{am}\right.$ to $6 \mathrm{pm}$ ) of $355 \mathrm{ml} / 0.25 \mathrm{~m}^{2}$ were recorded in modified solar still as compared to $305 \mathrm{ml}$ $10.25 \mathrm{~m}^{2}$ in conventional solar still. As in the second case after increasing the quantity of PCM by $0.25 \mathrm{~kg}$ the performance has been monitored. Slightly better Yield has been recorded.

Figure 21 displays day-productivity and overall productivity of fresh water output in both the solar stills. Overall productivity ( $24 \mathrm{hrs}$. basis) of $490 \mathrm{ml} / 0.25 \mathrm{~m}^{2}$ were recorded in modified solar still (encapsulated with $0.5 \mathrm{~kg}$ of $\mathrm{MgSO}_{4} .7 \mathrm{H}_{2} \mathrm{O}$ ) as compared to $350 \mathrm{ml} / 0.25 \mathrm{~m}^{2}$ in conventional solar still. While, day-time productivity $\left(8 \mathrm{am}\right.$ to $6 \mathrm{pm}$ ) of $365 \mathrm{ml} / 0.25 \mathrm{~m}^{2}$ were recorded in modified solar still as compared to $295 \mathrm{ml}$ $10.25 \mathrm{~m}^{2}$ in conventional solar still. As in the third case after increasing the quantity of PCM to $1 \mathrm{~kg}$ the performance has been monitored. More Yield has been recorded. This implies that as the quantity of PCM increases the quantity of yield get increases.

Figure 22 displays overall (24 hrs.) distilled water yields of $450,475,490 \mathrm{ml} / 0.25 \mathrm{~m}^{2} /$ day for the modified solar still encapsulated with $0.5,0.75$ and $1 \mathrm{Kg}$ of $\mathrm{MgSO}_{4} .7 \mathrm{H}_{2} \mathrm{O}$ respectively as compared to 352 $\mathrm{ml} / 0.25 \mathrm{~m}^{2} /$ day for conventional solar still. Here at a glance considering all the combinations the performance have been compared. It has been observed that at higher quantity of PCM ,more heat storage effect have been observed and better yield has been recorded.

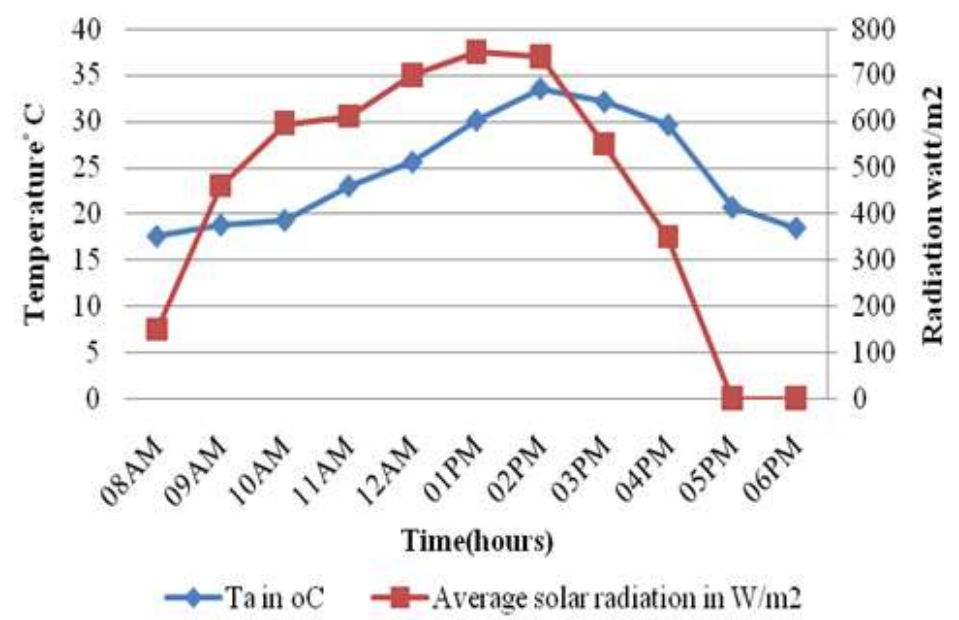

Figure 6. Variation of solar insolation with ambient temperature on $01 / 11 / 2018$

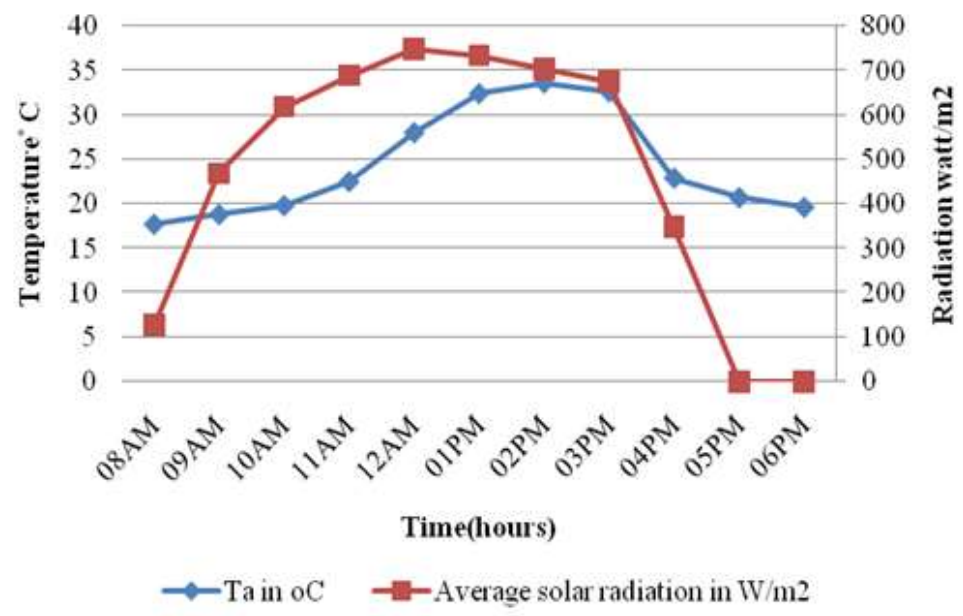

Figure 7. Variation of solar insolation with ambient temperature on 04/11/2018 
Journal of Thermal Engineering, Research Article, Vol. 7, No. 2, Special Issue 13, pp. 196-214, February, 2021

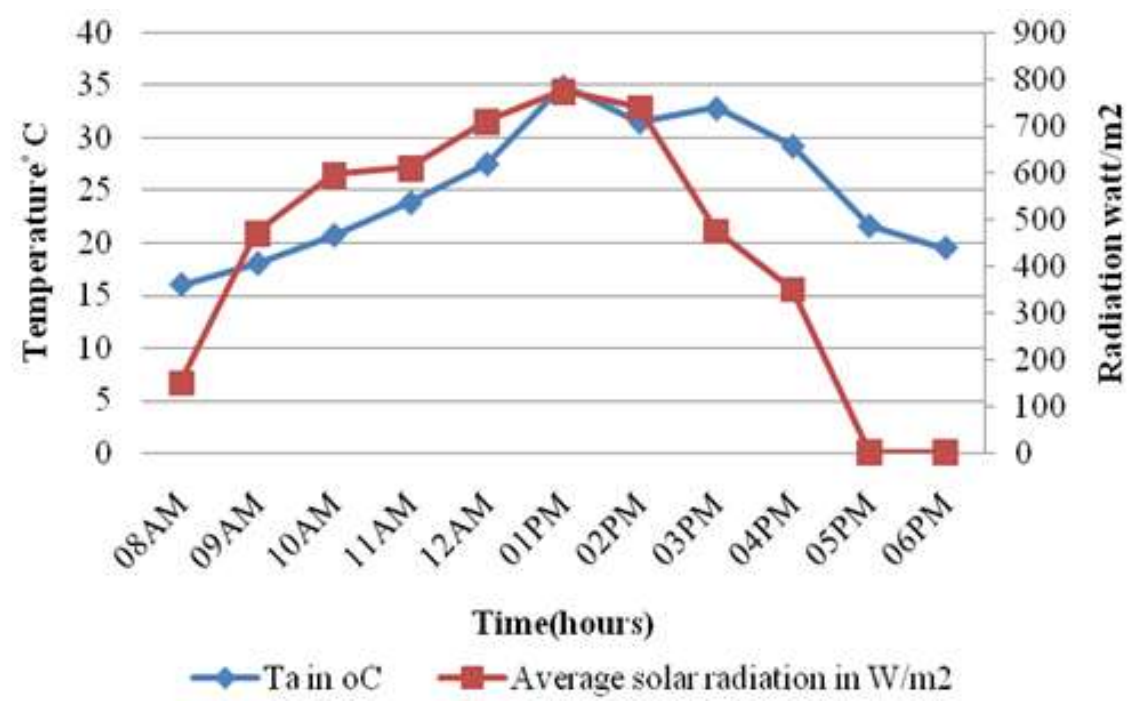

Figure 8. Variation of solar insolation with ambient temperature on 08/11/2018

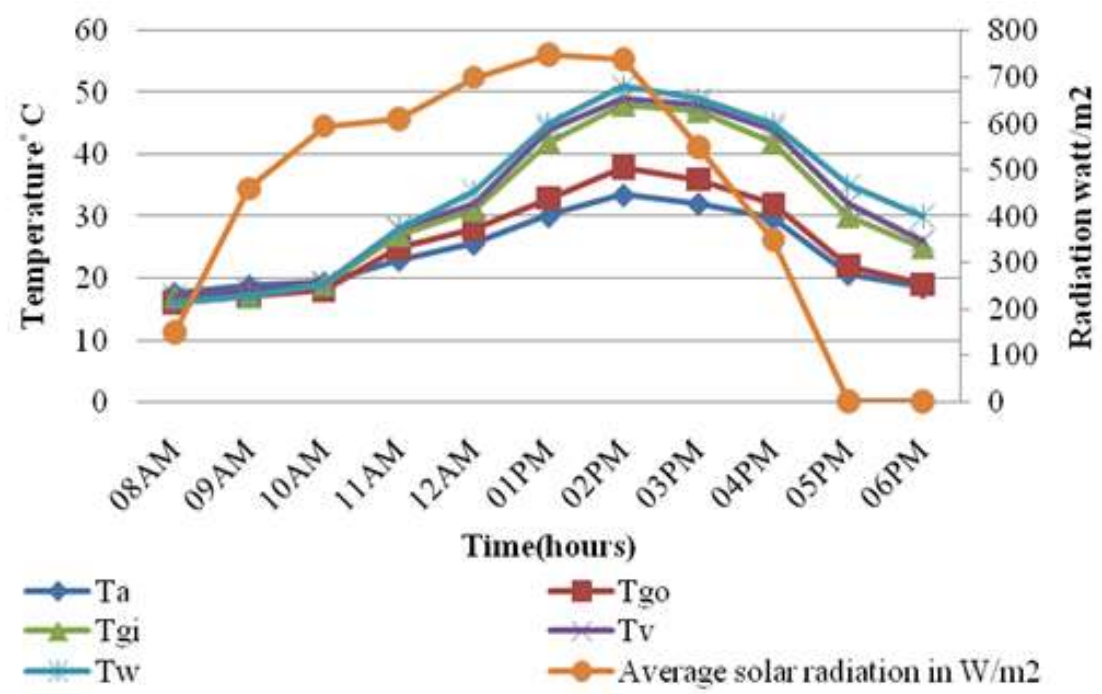

Figure 9. Variation of different temperatures for solar still without PCM
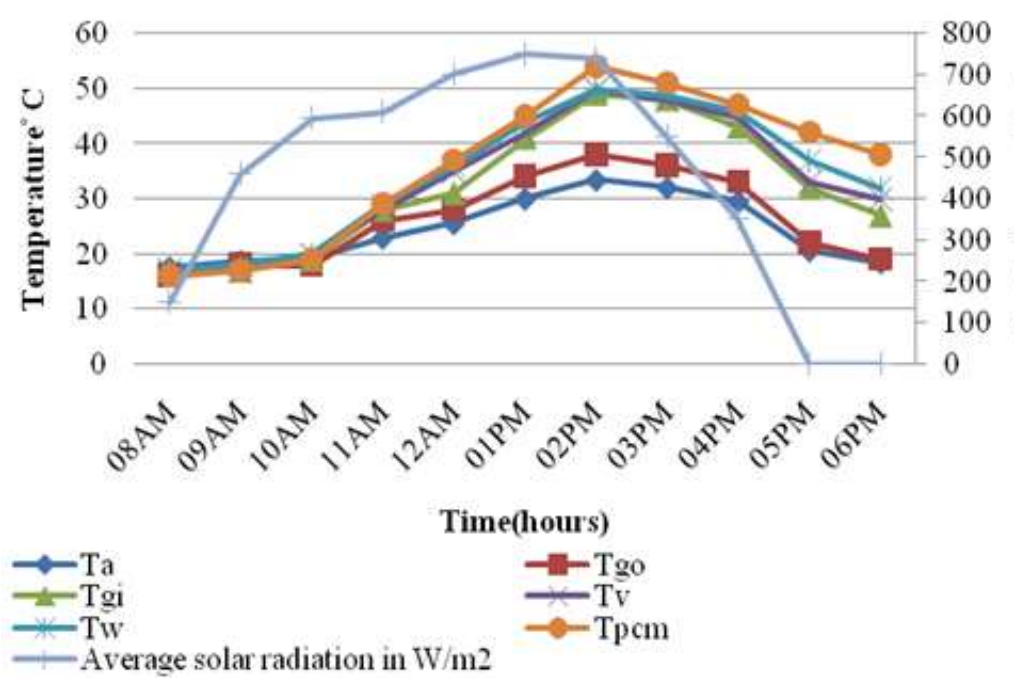

Figure 10. Variation of different temperatures for solar still with PCM of $0.5 \mathrm{Kg}$ 
Journal of Thermal Engineering, Research Article, Vol. 7, No. 2, Special Issue 13, pp. 196-214, February, 2021

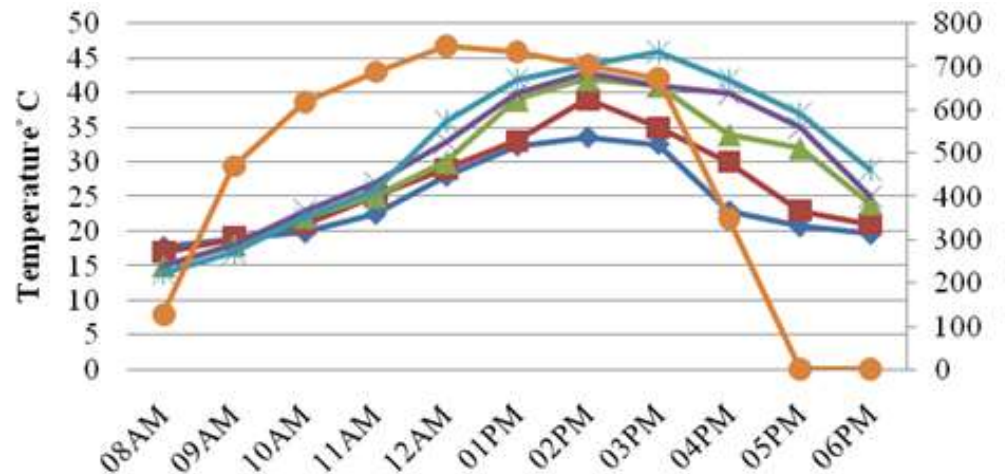

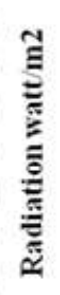

Time(hours)

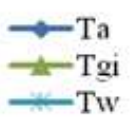

$\longrightarrow$ Tgo
$\longrightarrow$ Tv
$\longrightarrow$ Average solar radiation in $\mathrm{W} / \mathrm{m} 2$

Figure 11. Variation of temperatures for conventional still without PC

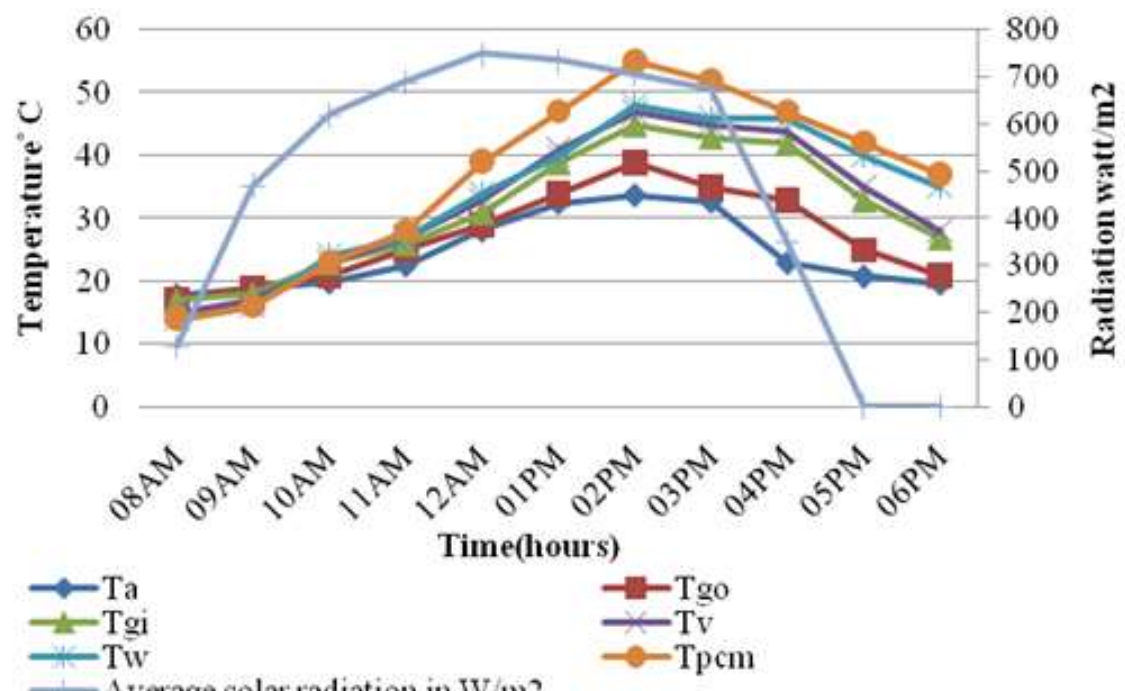

Figure 12. Variation of temperatures for still with $\mathrm{PCM}$ of $0.75 \mathrm{Kg}$

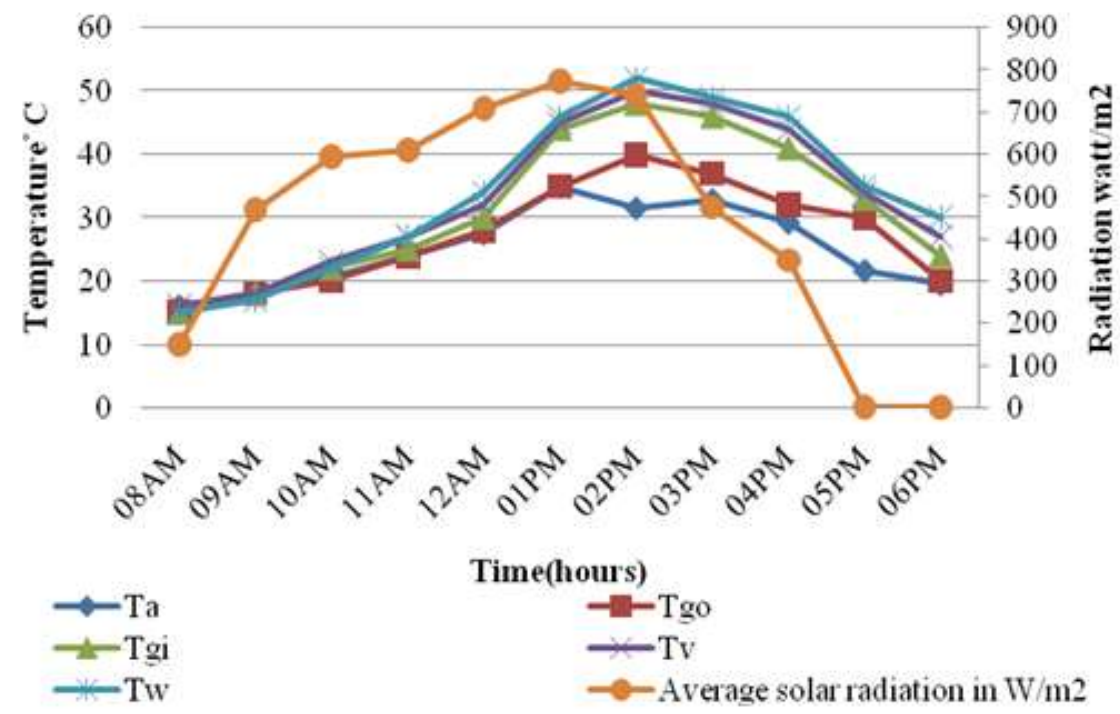

Figure 13. Variation of temperatures for still without PCM 
Journal of Thermal Engineering, Research Article, Vol. 7, No. 2, Special Issue 13, pp. 196-214, February, 2021

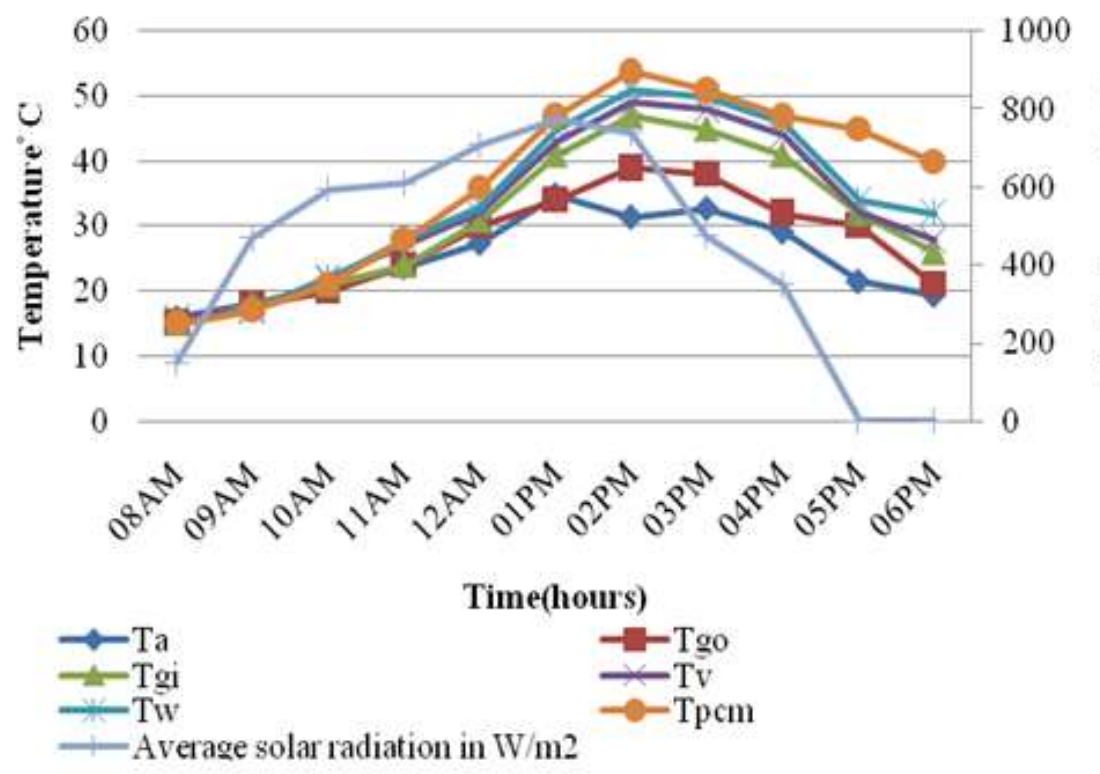

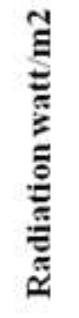

Figure 14. Variation of temperatures for still with $\mathrm{PCM}$ of $1 \mathrm{Kg}$

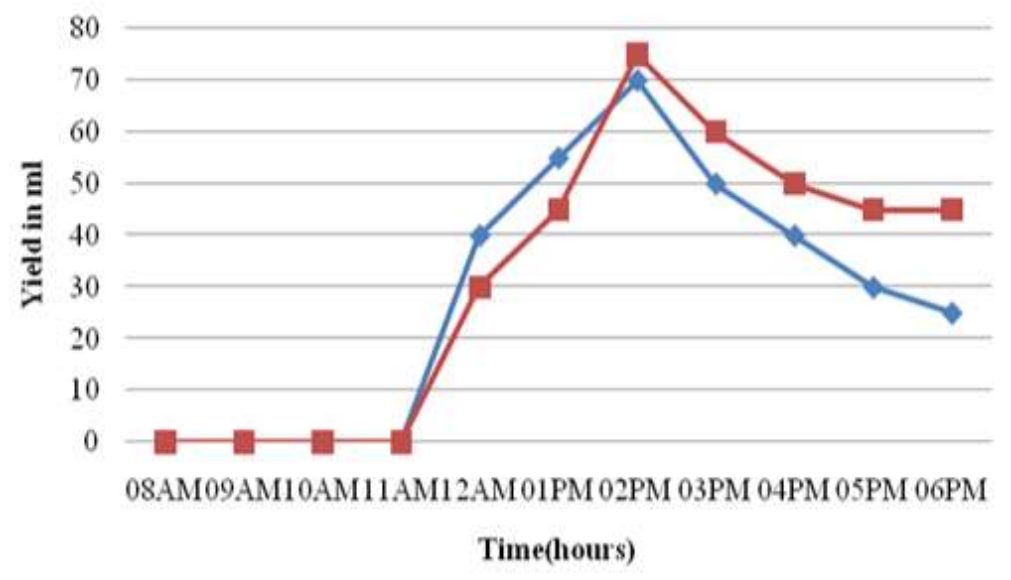

$\rightarrow$ withoutPCM $\rightarrow$-with $\mathrm{PCM}(0.5 \mathrm{Kg})$

Figure 15. Variation of fresh water output at $5 \mathrm{~cm}$ water depth on $01 / 11 / 2018$

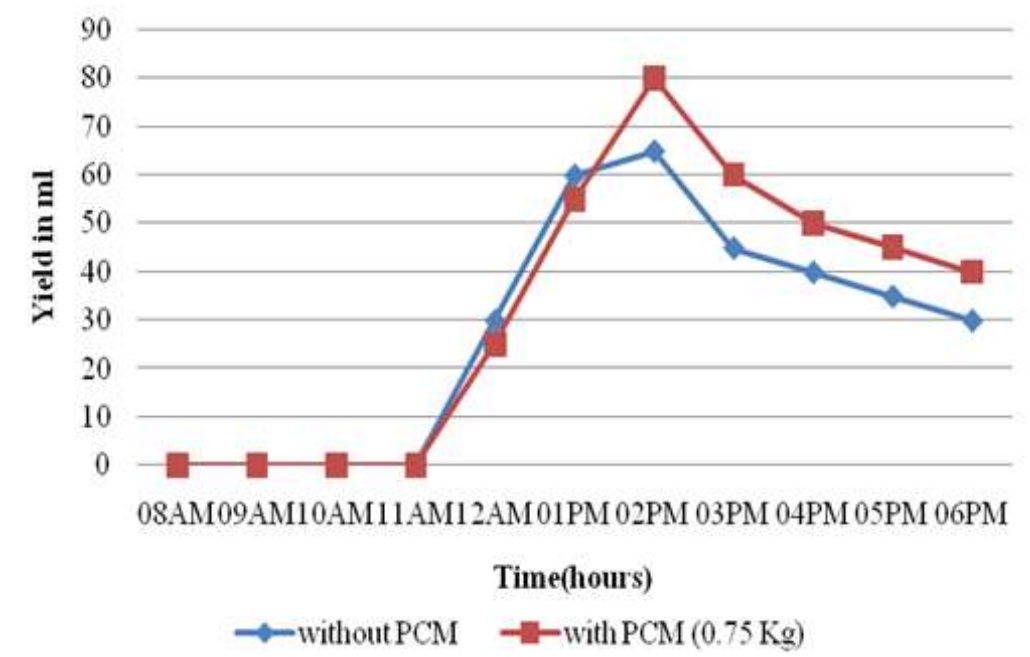

Figure 16. Hourly variation of distillate of both still for $5 \mathrm{~cm}$ water depth on $04 / 11 / 2018$ 
Journal of Thermal Engineering, Research Article, Vol. 7, No. 2, Special Issue 13, pp. 196-214, February, 2021

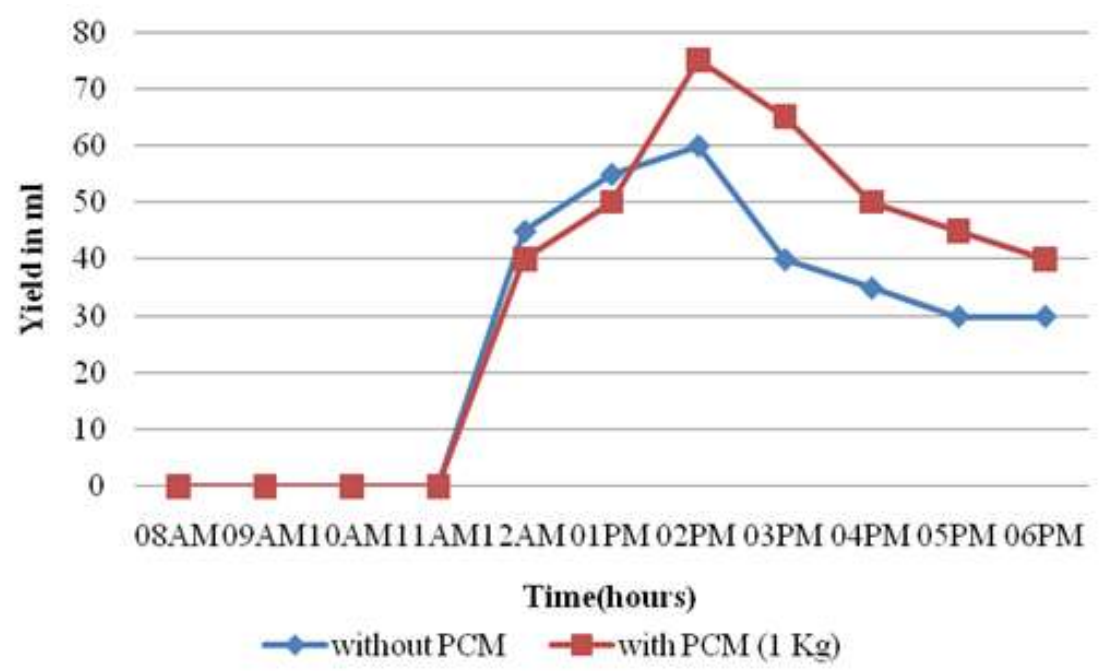

Figure 17. Variation of fresh water output at $5 \mathrm{~cm}$ water depth on $08 / 11 / 2018$

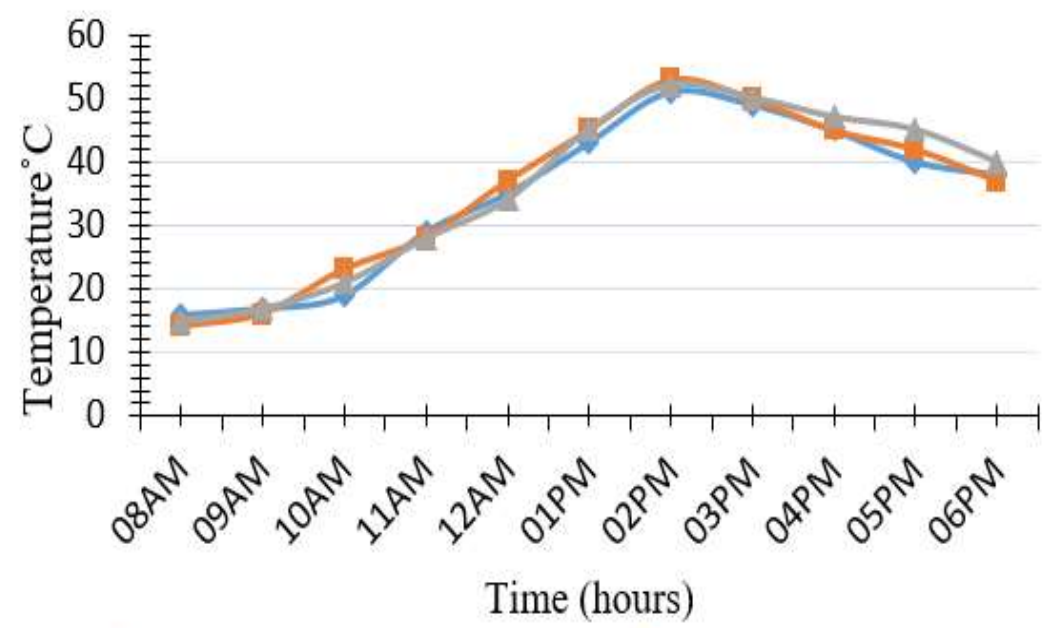

\section{$\rightarrow$ Tpcm for $0.5 \mathrm{Kg} \mathrm{PCM} \quad-$ Tpcm for $0.75 \mathrm{Kg} \mathrm{PCM}$ - Tpcm for $1 \mathrm{Kg}$ PCM}

Figure 18. Variation of PCM temperature for different concentration

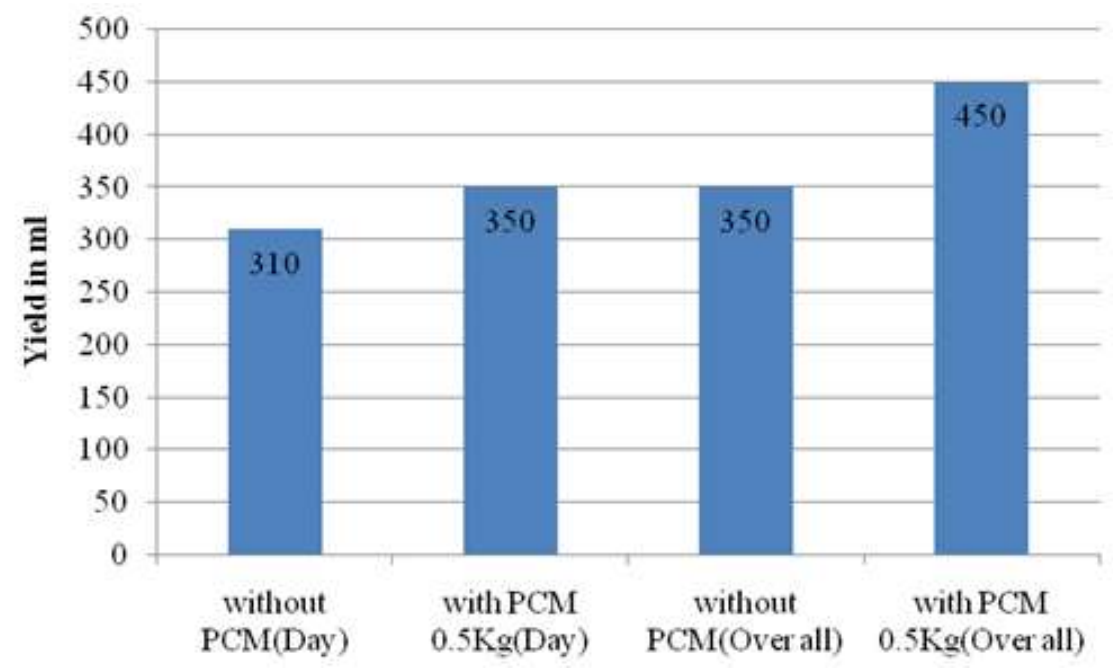

Figure 19. Variation of distillate productivity in 10 hours $(08.00 \mathrm{am}$ to $06.00 \mathrm{pm})$ and 24 hours at $5 \mathrm{~cm}$ water depth 
Journal of Thermal Engineering, Research Article, Vol. 7, No. 2, Special Issue 13, pp. 196-214,

February, 2021

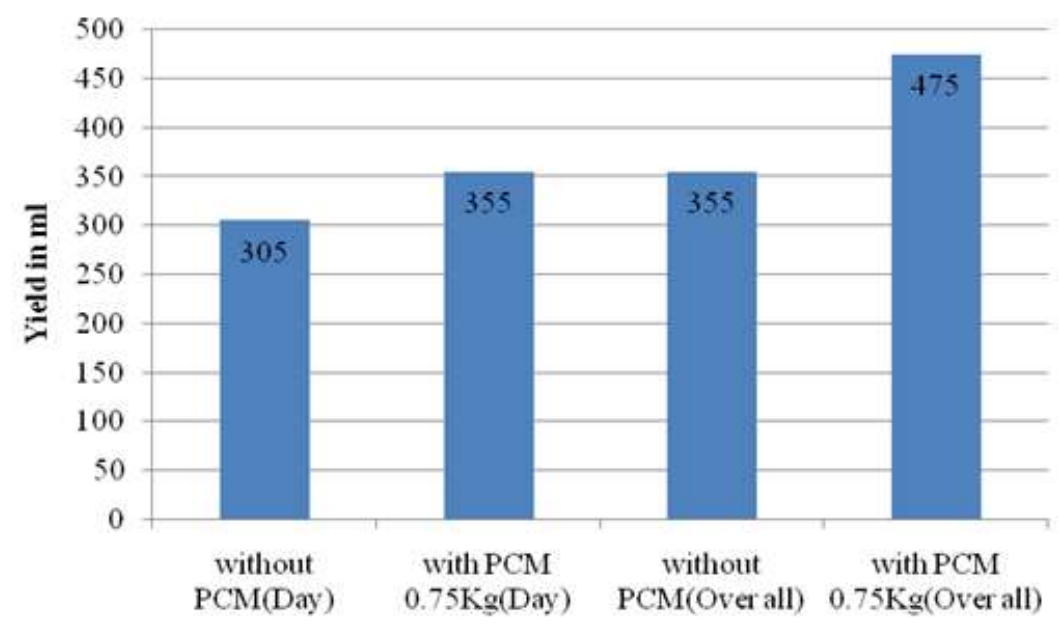

Figure 20. Variation of distillate productivity in 10 hours $(08.00 \mathrm{am}$ to $06.00 \mathrm{pm})$ and 24 hours (overall) at $5 \mathrm{~cm}$ water depth

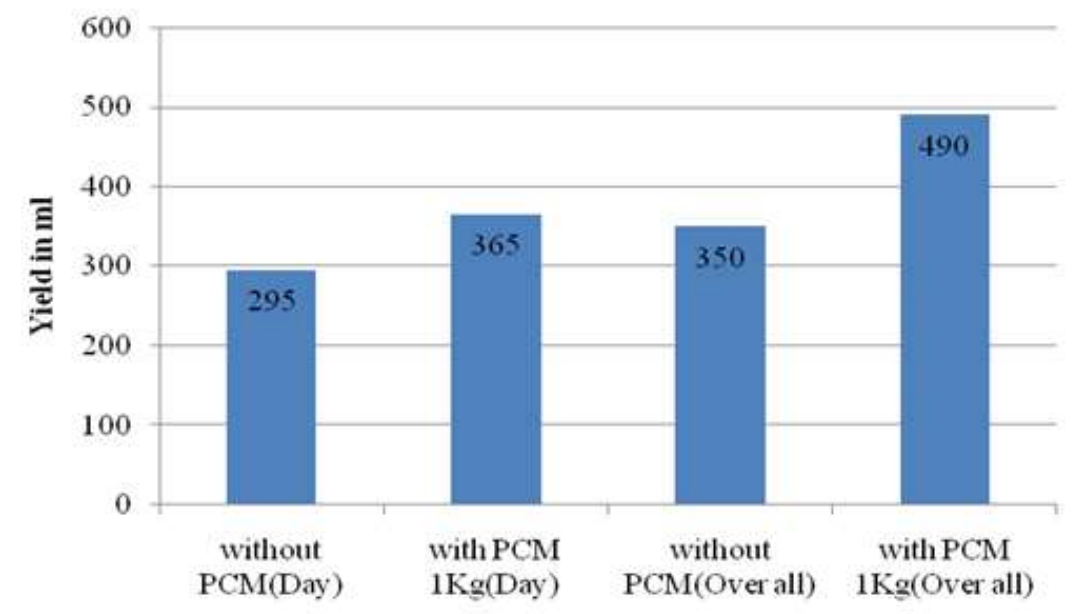

Figure 21. Variation of distillate productivity in 10 hours $(08.00 \mathrm{am}$ to $06.00 \mathrm{pm})$ and 24 hours (overall) at $5 \mathrm{~cm}$ water depth

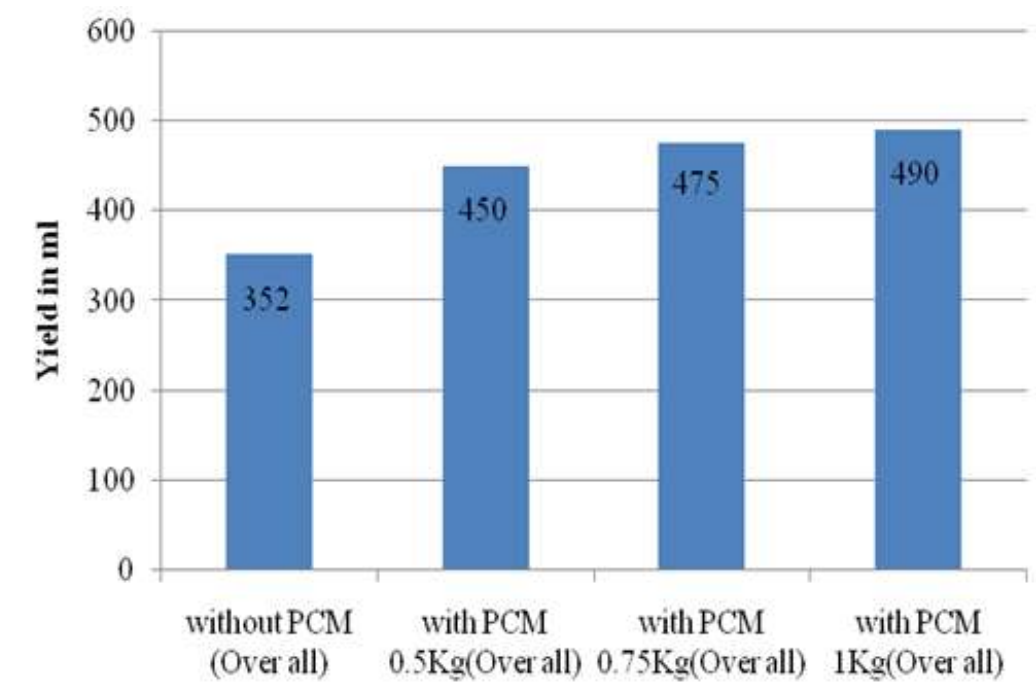

Figure 22. Variation of distillate productivity without PCM and with PCM for 24 hours (overall) at $5 \mathrm{~cm}$ water depth. Considering all the combinations 


\section{CONCLUDING REMARKS}

Different sets of Experiment were conducted with encapsulation of $\mathrm{MgSO}_{4} .7 \mathrm{H}_{2} \mathrm{O}$ as Phase change material in a double slope solar still. An experimental comparison is done with the conventional solar still without $\mathrm{MgSO}_{4} .7 \mathrm{H}_{2} 0$. Some important conclusions drawn include;

- Day water productivity of solar stills encapsulated with 25, 37.5, 50 grams of 20 capsules (each) were $1400,1420,1460 \mathrm{ml} / \mathrm{m}^{2}$ recorded as compared to $1240,1220,1180 \mathrm{ml} / \mathrm{m}^{2}$ for solar still without $\mathrm{MgSO}_{4} .7 \mathrm{H}_{2} 0$ at water depth of $5 \mathrm{~cm}$.

- Overall productivity of solar stills encapsulated with 25, 37.5, 50 grams of 20 capsules were 1800 , $1900,1960 \mathrm{ml} / \mathrm{m}^{2} /$ day recorded as compared to $1400,1420,1400 \mathrm{ml} / \mathrm{m}^{2} /$ day of solar still without $\mathrm{MgSO}_{4} .7 \mathrm{H}_{2} \mathrm{O}$.

- Day productivity and overall productivity is higher for solar still containing $50 \mathrm{~g}$ capsules as compared to other two solar stills $(25,37.5$ grams of capsules).

- The daytime productivity of solar still contains $50 \mathrm{~g}$ capsules of $\mathrm{MgSO}_{4} .7 \mathrm{H}_{2} 0$ is $23 \%$ higher than conventional solar still without $\mathrm{MgSO}_{4} .7 \mathrm{H}_{2} 0$ and overall yield increased by $42.85 \%$.

- Choice of sensible heat storage material plays a significant role in increasing the yield of fresh water solar still. Lesser the specific heat leads to more heat addition and constant rejection of heat into the water for continuous and fast evaporation from the surface.

- Likewise, the actual difference in temperature between water surface and glass improves the yield of solar still. While measuring the yield of solar still with energy storage material the temperature difference increased by $80 \%$ as compared to the solar still without PCM.

- Tests showed that the water yield is as pure as rain water and there were no harmful salts in it. It is recommended that for more quantity of PCM, the still will be more effective. The heat storage materials which are used in this work are economically appropriate for solar still to enhance the output and efficiency.

- Hence, it is concluded that distillation yield is always better in solar still encapsulated with $\mathrm{MgSO}_{4} .7 \mathrm{H}_{2} \mathrm{O}$ as PCM.

\section{NOMECLATURE}

A Area of absorber $\left[\mathrm{m}^{2}\right]$

$\mathrm{C}_{\mathrm{p}} \quad$ Heat capacity $\left[\mathrm{J} / \mathrm{kg}{ }^{\circ} \mathrm{C}\right]$

$\mathrm{D}_{\mathrm{w}} \quad$ Basin water depth $[\mathrm{cm}]$

$\mathrm{I}_{\mathrm{g}} \quad$ Normal solar radiation/insolation $\left[\mathrm{W} / \mathrm{m}^{2}\right]$

$\mathrm{L} \quad$ length of glass cover [m]

$\mathrm{M}_{\mathrm{pcm}} \quad$ Mass of PCM [kg]

PCM Phase change material

$\mathrm{T}_{\mathrm{a}} \quad$ Temperature of atmospheric air $\left[{ }^{\circ} \mathrm{C}\right]$

$\mathrm{T}_{\mathrm{gi}} \quad$ Temperature of inside glass surface $\left[{ }^{\circ} \mathrm{C}\right]$

$\mathrm{T}_{\mathrm{go}} \quad$ Temperature of outside glass surface $\left[{ }^{\circ} \mathrm{C}\right]$

$\mathrm{T}_{\mathrm{pcm}} \quad$ Temperature of encapsulated PCM $\left[{ }^{\circ} \mathrm{C}\right]$

$\mathrm{T}_{\mathrm{v}} \quad$ Temperature of vapor inside still $\left[{ }^{\circ} \mathrm{C}\right]$

$\mathrm{T}_{\mathrm{w}} \quad$ Temperature of Water inside still $\left[{ }^{\circ} \mathrm{C}\right]$

\section{REFERENCES}

[1] S. Howard. The UNESCO courier. 2019. https://en.unesco.org/news/billions-deprived-right-water.

[2] Omid Mahian, Ali Kianifar, Raviwat Srisomba, Phubate Thiangtham. Solar distillation practice for water desalination systems. Journal of Thermal Engineering 2015;1:287-288.

[3] Law Torres Sevilla, Jovana Radulovic. Mathematical modelling of low grade thermal energy storage using an encapsulated liquid medium. Journal of Thermal Engineering 2020;6:214-226. https://doi.org/10.18186/thermal.711327.

[4] Korti abdel illah nabil. Numerical simulation on the effect of latent heat thermal energy storage unit. Journal of Thermal Engineering 2016;2:598-606. https://doi.org/10.18186/jte.00934.

[5] Insan Ullah, Mohammad G. Rasul. Recent developments in solar thermal desalination technologies: A review. Energies 2019;12:119. https://doi:10.3390/en12010119. 
[6] Edward Jones, Manzoor Qadir, Michelle T. H. van Vliet, Vladimir Smakhtin, Seongmu Kang. The state of desalination and brine production: A global outlook. Science of The Total Environment 2019;657:13431356. https://doi.org/10.1016/j.scitotenv.2018.12.076.

[7] O.K. Buros. The ABCs of Desalting. International Desalination Association, USA, second edition 1990.

[8] Thomas M. Missimer, Robert G. Malivab. Environmental issues in seawater reverse osmosis desalination: Intakes and Outfalls. Desalination 2018;434:198-215. https://doi.org/10.1016/j.desal.2017.07.012.

[9] Mahmoud Shatat, Saffa B. Riffat. Water desalination technologies utilizing conventional and renewable energy sources. International Journal of Low-Carbon Technologies 2014;9:1-19. https://doi.org/10.1093/ijlct/cts025.

[10] D. B. Singh, G. N. Tiwari. Enhancement in energy metrics of double slope solar still by incorporating N identical PVT collectors. Solar Energy 2017;143:142-161. https://doi.org/10.1016/j.solener.2016.12.039.

[11] Vishwanath Kumar Panangipalli, Anil Kumar, Om Prakash, Ajay Kaviti. Solar stills system design: A review. Renewable and Sustainable Energy Reviews 2015;51:153-181. https://doi.org/10.1016/j.rser.2015.04.103.

[12] M.M.A Khan, NI Ibrahim, IM Mahbubul, HM Ali, R Saidur, FA Al-Sulaiman. Evaluation of solar collector designs with integrated latent heat thermal energy storage: A review. Solar Energy 2018;166:334-350. https://doi.org/10.1016/j.solener.2018.03.014.

[13] Tauseef-Ur-Rehman, Hafiz Ali, Muhammad Mansoor Janjua, Uzair Sajjid, Wei Mon Yan. A critical review on heat transfer augmentation of phase change materials embedded with porous materials/foams. International Journal of Heat and Mass Transfer 2019;135:649-673. https://doi.org/10.1016/j.ijheatmasstransfer.2019.02.001.

[14] Siddharth Roy, Lazarus Godson Asirvatham, Deepak Kunhappan, Enoch Cephas, Somchai Wongwises. Heat transfer performance of silver/water nanofluid in a solar flat-plate collector. Journal of Thermal Engineering 2015;1:104-112. https://doi.org/10.18186/jte.29475.

[15] Lazarus Godson. Nanofluid heat transfer and applications. Journal of Thermal Engineering 2015;1:113115. https://doi.org/10.18186/jte.93344.

[16] N. Tokgoz, E. Alıç, Ö. Kaşka, M. M. Aksoy. The numerical study of heat transfer enhancement using $\mathrm{Al}_{2} \mathrm{O}_{3-}$ water nanofluid in corrugated duct application. Journal of Thermal Engineering 2018;4:1984-1997. https://doi.org/10.18186/journal-of-thermal-engineering.409655

[17] R. Ravisankar, V.S.K. Venkatachalapathy, N. Alagumurthi. Application of nanotechnology to improve the performance of tractor radiator using Cu-water nanofluid. Journal of Thermal Engineering 2018;4:21882200.

[18] Tauseef-ur- Rehman, Hafiz Muhammad Ali. Experimental investigation on paraffin wax integrated with copper foam based heat sinks for electronic components thermal cooling. International Communications in Heat and Mass Transfer 2018;98:155-162. https://doi.org/10.1016/j.icheatmasstransfer.2018.08.003

[19] Tabet Ismail, Mohamed Kezzar, Nouredine Nafire, Abdelkader Khanetout. A new analytical investigation of natural convection of non-newtonian nanofluids flow between two vertical flat plates by the generalized decomposition method (GDM). Journal of Thermal Engineering 2018;4:2496-2508. https://doi.org/10.18186/thermal.465731.

[20] Khadija Madani, Rejeb Ben Maad, Aissa Abidi-Saad. Numerical investigation of cooling a ribbed micro channel using nanofluid. Journal of Thermal Engineering 2018;4:2408-2422. https://doi.org/10.18186/thermal.465650.

[21] M. Almakki, H. Mondal, P. Sibanda. Entropy generation in MHD flow of viscoelastic nanofluids with homogeneous-heterogeneous reaction, partial slip and nonlinear thermal radiation. Journal of Thermal Engineering 2020;6:327-345.

[22] Hasan Mousa, Jamil Naser, Omar Houche. Using PCM as energy storage material in water tanks: Theoretical and experimental investigation. Journal of Energy Storage 2019;22:1-7. https://doi.org/10.1016/j.est.2019.01.018.

[23] Kantesh D.C. Design of solar still using phase changing material as a storage medium. International Journal of Scientific \& Engineering Research 2012;3:1-5.

[24] Hemin Thakkar, Dr. Hitesh Panchal. Performance investigation on solar still with PCM and Nanocomposites: Experimental investigation. IJRSI 2015;3:334-339.

[25] Miqdam T Chaichan, Hussein A Kazem. Using aluminium powder with PCM (Paraffin Wax) to enhance single slope solar water distiller productivity in Baghdad - Iraq winter weathers. International Journal of Renewable Energy Research 2015;5:251-257.

[26] Sagar Suresh Agrawal. Distillation of water- using solar energy with Phase Change Materials. IJERA 2015:133-138. 
[27] G. Rajasekhara, M. Eswaramoorthy. Performance evaluation on solar still integrated with nano-composite phase change materials. Applied Solar Energy 2015;51:15-21. https://doi.org/10.3103/S0003701X15010119.

[28] H. S. Deshmukh, S. B. Thombre. Experimental study of an integrated single basin solar still with bees wax as a passive storage material. International Journal of Thermal Technologies 2015;5:226-231.

[29] Maheep Kumar, Ajeet Kumar Rai. Performance study of a phase change material assisted solar still. IJARET 2016;7: 60-67.

[30] Mouna Hamed, Ammar B. Brahim. Theoretical model of a flat plate solar collector integrated with phase change material. International Journal of Energy and Power Engineering 2015;9:1420-1427.

[31] P. Sundaram, R. Senthil. Productivity enhancement of solar distillation system using paraffin wax. Int. J. Chem. Sci. 2016;14:2339-2348.

[32] Bharat Kumar Patil, Sanjay Dambal. Design and experimental performance analysis of solar still using phase changing materials and sensible heat elements. IJRMET 2016;6:144-149.

[33] Mauli K. Dube, Akshay T. Dhalpe, Gaurav N. Devkate, Mayur D. Kadam. A study of performance of solar still with Stearic Acid as PCM. Journal for Research 2017;3:5-8.

[34] T Rehman, HM Ali, A Saieed, W Pao, M Ali. Copper foam/PCMs based heat sinks: An experimental study for electronic cooling systems. International Journal of Heat and Mass Transfer 2018;127:381-393. https://doi.org/10.1016/j.ijheatmasstransfer.2018.07.120

[35] ZA Qureshi, HM Ali, S Khushnood. Recent advances on thermal conductivity enhancement of phase change materials for energy storage system: a review. International Journal of Heat and Mass Transfer 2018;127:838-856. https://doi.org/10.1016/j.ijheatmasstransfer.2018.08.049.

[36] Mohammad Mumtaz A. Khan, Nasiru I. Ibrahim, I.M. Mahbubul, Hafiz Muhammad. Ali, R. Saidur, Fahad A. Al-Sulaiman. Evaluation of solar collector designs with integrated latent heat thermal energy storage: A review. Solar Energy 2018;166:334-350. https://doi.org/10.1016/j.solener.2018.03.014.

[37] A.E. Kabeel, Y. A. F. El-Samadony, Wael M. El-Maghlany. Theoretical performance comparison of solar still using different PCM. Twentieth International Water Technology Conference, IWTC20 Hurghada 2017: 424-432.

[38] M. Ravi Kumar, M. Sridhar, S. Madhan Kumar, C. Vignesh Vasanth. Experimental Investigation of Solar water Desalination with Phase Change Material and TiO2. Imperial Journal of Interdisciplinary Research 2017;3:1128-1134.

[39] Avesahemad S. N. Husainy, Omkar S. Karangale, Vinayak Y Shinde. Experimental study of double slope solar distillation with and without effect of latent thermal energy storage. Asian Review of Mechanical Engineering 2017;6:15-18.

[40] Piyush Pal, Pankaj Yadav, Rahul Dev, Dhananjay Singh. Performance analysis of modified basin type double slope multi-wick solar still. Desalination 2017;422:68-82. https://doi.org/10.1016/j.desal.2017.08.009.

[41] Hrushikesh Kulkarni, Chinmay Kute, Chirag Patel, Akshay Tavse. Experimental investigation and performance evaluation of solar still using PCM. IRJET 2018;5:1109-1118.

[42] A.E. Kabeel, Y.A.F. El-Samadony, Wael M. El-Maghlany. Comparative study on the solar still performance utilizing different PCM. Desalination 2018;432:89-96. https://doi.org/10.1016/j.desal.2018.01.016.

[43] Wen-Long Cheng, Yan-Kai Huo, Yong-Le Nian. Performance of solar still using shape-stabilized PCM: Experimental and theoretical investigation. Desalination 2019;455:89-99. https://doi.org/10.1016/j.desal.2019.01.007.

[44] A.E. Kabeel, Mohamed Abdelgaied, M. Mahgoub. The performance of a modified solar still using hot air injection and PCM. Desalination 2016;379:102-107. http://dx.doi.org/10.1016/j.desal.2015.11.007.

[45] Meysam Faegh, Mohammad Behshad Shafii. Experimental investigation of a solar still equipped with an external heat storage system using phase change materials and heat pipes. Desalination 2017;409:128135. http://dx.doi.org/10.1016/j.desal.2017.01.023.

[46] Murat M. Kenisarin. Thermo-physical properties of some organic phase change materials for latent heat storage. A review. Solar Energy 2014;107:553-575. https://doi.org/10.1016/j.solener.2014.05.001.

[47] Fahad A. Al-Sulaiman et al. A review on current status and challenges of inorganic phase change materials for thermal energy storage systems. Renewable and Sustainable Energy Reviews 2017;70:1072-1089. http://dx.doi.org/10.1016/j.rser.2016.12.012.

[48] A. Shruthi, R. Pavithra, M. Durga. Desalination of brackish water using solar still with phase change material. IJARIIE 2018;4:2528- 2532.

[49] Chandrakant Wani, Praveen Kumar Loharkar. A Review of Phase Change Materials as an Alternative for Solar Thermal Energy Storage. Materials Today proceedings 2017;4:10264-10267.

https://doi.org/10.1016/j.matpr.2017.06.361. 
Journal of Thermal Engineering, Research Article, Vol. 7, No. 2, Special Issue 13, pp. 196-214,

February, 2021

[50] S. Shanmugan, S. Palani, B. Janarthanan. Productivity enhancement of solar still by PCM and Nanoparticles miscellaneous basin absorbing materials. Desalination 2018;433:186-198. https://doi.org/10.1016/j.desal.2017.11.045.

[51] Y. H. Siao, W .M .Yan, C. M. Lai. Transient characteristics of thermal energy storage in an enclosure packed with MPCM particles. Applied Thermal Engineering 2015;88:47-53. https://doi.org/10.1016/j.applthermaleng.2014.11.059

[52] A. Kasaeian, L. Bahrami, F. Pourfayaz, E. Khodabandeh, W.M. Yan. Experimental studies on the applications of PCMs and Nano-CPMs in building: a critical review. Energy and Buildings 2017;154:96-112. https://doi.org/10.1016/J.ENBUILD.2017.08.037.

[53] A. Arshad, H.M. Ali, S. Khushnood, M. Jabbal. Experimental investigation of PCM based round pin-fin heat sinks for thermal management of electronics: effect of pin-fin diameter. International Journal of Heat and Mass Transfer 2018;117:861-872. https://doi.org/10.1016...asstransfer.2017.10.008.

[54] H.M. Ali, A. Arshad, M. Jabbal, P. Verdin. Thermal management of electronics devices with PCMs filled pin-fin heat sinks: A comparison. International Journal of Heat and Mass Transfer 2018;117:1199-1204. https://doi.org/10.1016/j.ijheatmasstransfer.2017.10.065.

[55] HM Ali, A Arshad, MM Janjua, W Baig, U Sajjad. Thermal performance of LHSU for electronics under steady and transient operations modes. International Journal of Heat and Mass Transfer 2018;127:12231232. https://doi.org/10.1016/j.jheatmasstransfer.2018.06.120.

[56] C. J. Ho, C.R. Siao, W. M. Yan. Thermal energy storage characteristics in enclosure packed with MEPCM particles: an experimental and numerical study. Int. journal of heat and Mass Transfer 2014;73:88-96. https://doi.org/10.1016/j.ijheatmasstransfer.2014.01.056. 